\title{
16. UPPER CRETACEOUS-PALEOCENE FORAMINIFERA FROM SITE 208 (LORD HOWE RISE, TASMAN SEA), DSDP, LEG 21
}

\author{
Peter N. Webb, New Zealand Geological Survey, Lower Hutt, New Zealand
}

\section{INTRODUCTION}

The lowermost 55 meters penetrated at Site 208, Lord Howe Rise, Tasman Sea (Figure 1), consisted of 18 meters of Maestrichtian sediments overlain by 37 meters of Paleocene sediments. The Paleocene sediments are disconformably overlain by Middle Eocene sediments. The Maestrichtian sediments consist of light gray chalk and occasional chert. Bioturbation structures are common. A 0.5 -meter black chert with ghosts of lamination and burrows marks the Maestrichtian-Paleocene boundary. Paleocene sediments consist of pale gray to green gray chalks in which radiolarians, diatoms, and sponge fragments are common. Sediments are mottled and silicified with lenses of chalk, or predominantly chalk with silicified streaks. Foraminifera and nannoplankton are present in both Maestrichtian and Paleocene sediments. Foraminifera tend to be more abundant and best preserved in the Maestrichtian. Planktonic foraminifera dominate Maestrichtian assemblages and calcareous benthic foraminifera the Paleocene assemblages. The present study is based on the examination of forty-two 10-cc samples. Preliminary comments on these faunas were provided by Webb (1973).

\section{BIOSTRATIGRAPHY}

\section{Abathomphalus mayaroensis Zone}

The occurrence of $G$. (A.) mayaroensis Bolli in Samples 33-3 $(26-28 \mathrm{~cm})$ and $33-2(112-114 \mathrm{~cm})$ allows confident correlation with the A. mayaroensis Zone of Trinidad. This species occurs in very small numbers at Site 208 and exhaustive picking failed to provide specimens lower in this succession. The interval $33-3(95-97 \mathrm{~cm})$ down to $34-3$ $(124-126 \mathrm{~cm})$ (the lowermost core) also failed to provide Globorotruncana gansseri Bolli leaving open the question of whether this lower interval should be assigned to the $G$. mayaroensis or $G$. gansseri Zones. That this interval is certainly no older than the $G$. gansseri Zone is supported by the presence of Heterohelix glabrans (Cushman), Pseudotextularia deformis (Kikoine), Planoglobulina carseyae (Plummer), Rugoglobigerina rotundata Bronnimann, G. (Rugotruncana) circumnodifer (Finlay), Globotruncanella petaloidea (Gandolfi), and Hedbergella monmouthensis (Olsson). The occurrence of G. (Rugotruncana) circumnodifer (Finlay) allows correlation with the G. circumnodifer Zone of New Zealand (Webb, 1966, 1971).

Globoconcusa daubjergensis-Globorotalia pseudobulloides Zone (Figure 2)

The interval $30-4(29-31 \mathrm{~cm})$ to $31-3(111-113 \mathrm{~cm})$ contains quite abundant planktonics including Globigerina triloculinoides Plummer, Globorotalia pseudobulloides (Plummer), and Globorotalia compressa (Plummer). This interval is tentatively correlated with the Globoconcusa daubjergensis-Globorotalia pseudobulloides Zone.

\section{Globorotalia uncinata Zone (Figure 2)}

The interval $30-1(34-36 \mathrm{~cm})$ to $30-3(112-114 \mathrm{~cm})$ contains Globorotalia uncinata Bolli, Globorotalia pseudobulloides (Plummer), Globorotalia ehrenbergi Bolli, Chiloguembelina crinata (Glaessner), and Zeauvigerina teuria Finlay. The interval is correlated with the G. uncinata Zone.

\section{Globorotalia pusilla pusilla-G. angulata Zone (Figure 2)}

Globorotalia angulata(White) appears in 29-6 $(53-55 \mathrm{~cm}$ ) and ranges up to 29-2 (118-120 cm). Accompanying taxa include Globorotalia pusilla pusilla Bolli, Globorotalia pseudobulloides (Plummer), Globorotalia ehrenbergi Bolli, Globigerina triloculinoides Plummer, Globorotalia acarinata (Subbotina), G. mckannai (White), and Chiloguembelina crinata (Glaessner).

\section{Globorotalia pseudomenardii Zone (Figure 2)}

Taxa present in this zone include Globorotalia pseudomenardii Bolli, Globorotalia pusilla pusilla Bolli, Globorotalia pusilla laevigata Bolli, Globorotalia pseudobulloides (Plummer), Globigerina triloculinoides Plummer, Globorotalia acarinata (Subbotina), and Globorotalia mckannai (White).

\section{New Zealand Paleocene Zones (Figure 2)}

The Paleocene succession at Site 208 appears to provide a better Lower-Middle Paleocene planktonic succession than currently available in New Zealand. The interval correlated here with the $G$. daubjergensis-G. pseudobulloides is about equivalent to Jenkin's (1971) Globigerina pauciloculata Zone. The interval correlated here with the $G$. uncinata Zone, G. pusilla pusilla-G. angulata Zone, and G. pseudomenardii Zone correlates with part of Jenkin's (1971) Globigerina (Subbotina) triloculinoides Zone.

\section{NEW ZEALAND AND EUROPEAN STAGES}

New Zealand late Cretaceous and early Tertiary stages are defined principally on benthic taxa (Webb, 1970, 1971). Benthic taxa present in the Abathomphalus mayaroensis Zone sediments at Site 208 allow correlation with the uppermost Haumurian Stage of New Zealand (Figure 3). Diagnostic taxa include Gaudryina healyi Finlay, Dorothia elongata Finlay, and Frondicularia rakauroana (Finlay). The presence of Bolivinoides draco Marsson throughout the Cretaceous part of the succession confirms correlation with the Maestrichtian. 


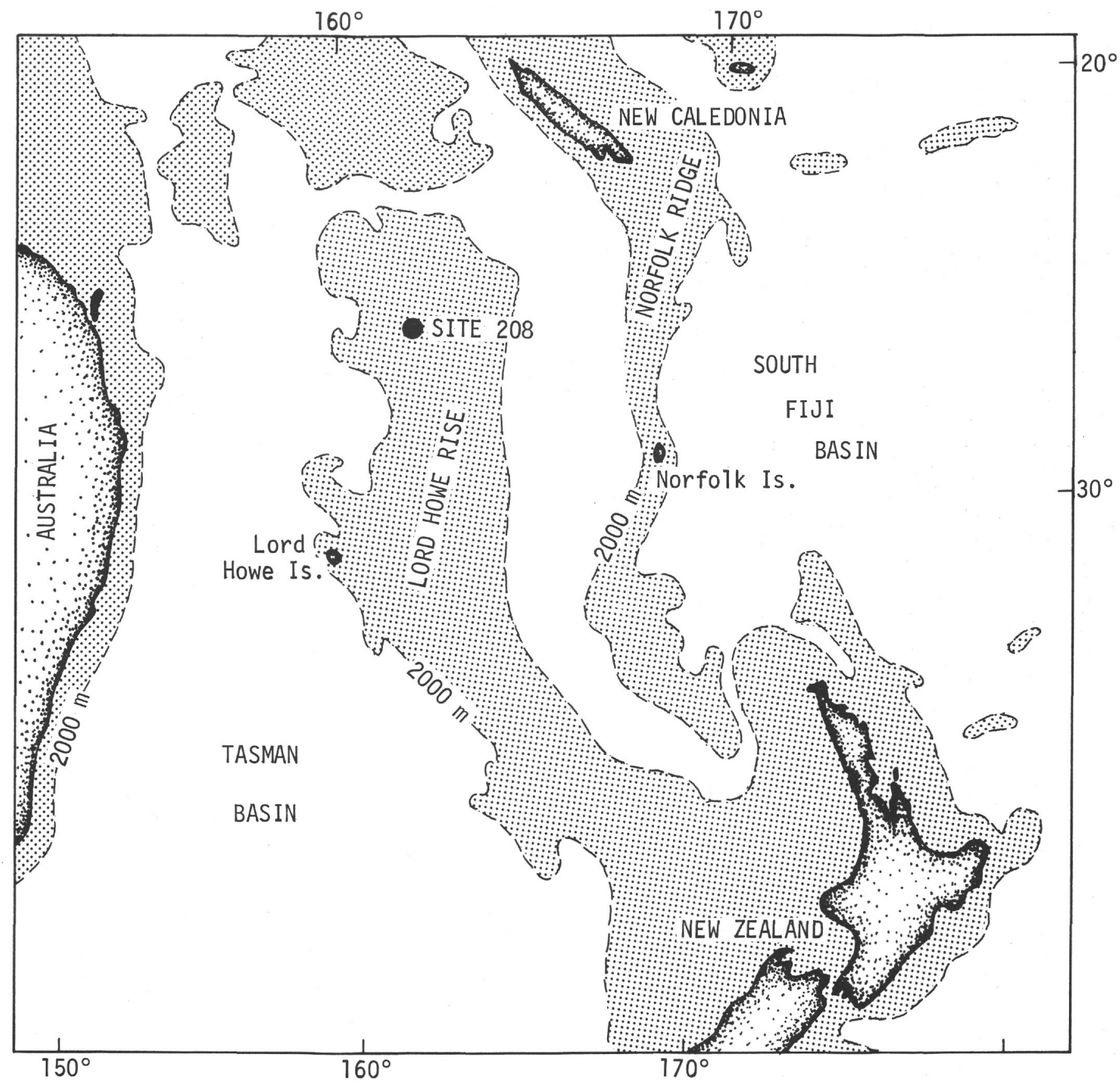

Figure 1. Map of Tasman Sea showing location of Site 208 on Lord Howe Rise.

Benthic taxa present in the three Paleocene zones at Site 208 allow correlation with the New Zealand Teurian Stage (Figure 3). This correlation is based on the presence of Gaudryina whangaia Finlay, Clavulina anglica (Cushman), Frondicularia teuria Finlay, and Neoflabellina semireticulata (Cushman and Jarvis). The Teurian Stage is the approximate equivalent of the European Danian-Thanetian Stage interval.

\section{GENERAL COMMENTS ON FORAMINIFERA}

A detailed list of all planktonic and benthic foraminifera is given in Figures 2 and 3, and some of the more significant planktonic taxa are shown in Plates 1 to 6 . The most striking feature of these microfaunas is the general similarity to the late Cretaceous and early Tertiary microfaunas of New Zealand, South America, Trinidad, and the Gulf Coast. This point has already been commented upon in a preliminary paper (Webb, 1973).

Tropical taxa are absent and the microfaunas share with those of New Zealand an extra-Tethyan southern high-latitude or Austral composition. Almost all the taxa encountered in Site 208 are also present in correlative New Zealand sediments. Planoglobulina carseyae (Plummer), Globigerinelloides subcarinatus (Bronnimann), Globotruncanella petaloidea (Gandolfi), Spiroplectammina ripleyensis Berry, Nodosaria gracilitatus Cushman, Pseudouvigerina 
cristata Marsson, Eouvigerina americana Cushman, Stensioina sp. and Bulimina sp. (reticulate ornament) are unknown in the New Zealand late Cretaceous. The latter taxon may be a new species. The main differences between the Maestrichtian of the two areas lies in their species diversity and proportions of planktonic to benthic taxa. The Lord Howe Rise material displays a much higher proportion of planktonics, but, conversely, a much lower species diversity. The Whangai Formation of southern Hawke's Bay is probably the nearest, facies-wise, to the Lord Howe Rise Maestrichtian. Webb (1971) reports a total of 164 species from the former area whereas only 85 occur in the latter. Planktonic diversity is the same at both localities, i.e., 12 species. The Hawke's Bay faunas contain 46 species of agglutinated benthics as against 11 in the Lord Howe Rise material and 106 species of calcareous benthics compared with 62 species. Much the same situation exists between the Paleocene foraminifera of the two areas. Planktonic diversity is similar at about 15 species but numbers of agglutinated and calcareous benthic taxa are again much higher in the New Zealand faunas. Notes on some of the more significant taxa are provided below.

\section{Gaudryina healyi Finlay}

This is an index species for the New Zealand Haumurian Stage where it occurs as quite large tests with a well-developed series of biserial chambers. Triserial early forms are present in small numbers. Test wall components are usually of medium sand size. Site 208 specimens never develop beyond the initial triserial stage and test components are extremely fine grained. The stratigraphic range of this important benthic is the same at both localities, the upper limit being the Maestrichtian-Paleocene boundary.

\section{Gaudryina whangaia Finlay}

This species appears in Sample 31-3 (111-113 cm) low in the Paleocene and persists in low numbers to the uppermost sample. Its range appears to be the same as in New Zealand where it is an index for the Teurian Stage.

\section{Dorothia elongata Finlay}

D. elongata is restricted to the Maestrichtian at Site 208 and its range therefore conforms to that known in New Zealand where it is an index species for the Haumurian Stage.

\section{Dorothia biformis Finlay}

D. biformis is restricted to the Maestrichtian at Site 208 but ranges into the Paleocene (Teurian) in New Zealand. New Zealand material develops to a large size with a well-developed series of biserial chambers. The Lord Howe Rise material seldom develops past the initial polyserial growth stage.

\section{Conotrochammina whangaia Finlay}

A single specimen occurs in Sample 30-6(116-118 cm) (Paleocene). This is an index species for Teurian in New Zealand. A single specimen is also present low in the Maestrichtian at Site 208 and is attributed to downhole reworking.

\section{Clavulina anglica (Cushman)}

Common throughout the Paleocene succession. An index for Teurian in the New Zealand Paleocene. Site 208 specimens are confined mostly to the initial triserial portion whereas a long uniserial series of chambers is common in New Zealand material. Wall components in the Site 208 specimens are generally finer grained than their New Zealand counterparts.

\section{Frondicularia teuria Finlay}

Fragments of this large species are restricted to the Paleocene sediments at Site 208. The stratigraphic range is the same as that in New Zealand where this is an index species for the Teurian Stage.

\section{Neoflabellina semireticulata (Cushman)}

A few specimens, mostly early growth forms, are restricted to the Paleocene. A junior synonym, Neoflabellina thalmanni (Finlay), is a Teurian index (Webb, 1970).

\section{Gavelinella beccariiformis (White)}

This is the dominant benthic species in all Maestrichtian samples and in a number of those from the Paleocene. This species is also a common Maestrichtian-Paleocene benthic in New Zealand (Webb, 1970). It constitutes up to $12 \%$ of Maestrichtian faunas and up to $33 \%$ of Early Paleocene faunas at Site 208 .

\section{Heterohelix striata (Ehrenberg) \\ (Plate 1, Figures 1-3).}

$H$. striata is the dominant taxon in all but the uppermost Maestrichtian sample. Nonstriate heterohelicids equivalent to $H$. globulosa were not encountered.

\section{Heterohelix glabrans (Cushman) (Plate 1, Figure 4)}

Present in most samples but always completely subordinate to Heterohelix striata (Ehrenberg).

\section{Chiloguembelina crinata (Glaessner)}

Isolated specimens occur in several Paleocene samples. The genus is, on the whole, very poorly represented at Site 208.

\section{Chiloguembelina wilcoxensis (Cushman \& Ponton)} (Plate 2, Figures 1-2).

Quite common in the uppermost Paleocene sample, $29-1(45-47 \mathrm{~cm})$, which is correlated with the $G$. pseudomenardii Zone. It enters the record at about the same level as proposed by Beckmann (1957) in Trinidad but somewhat earlier than in New Zealand (Jenkins, 1971).

\section{Zeauvigerina teuria Finlay}

(Plate 2, Figures 3-4).

Restricted to the G. uncinata Zone and lower part of the G. pusilla pusilla-G. angulata Zone. Occurs in some abundance in Sample 30-4(29-31 cm). A few poorly preserved specimens occur in the $G$. daubjergensis- $G$. pseudobulloides Zone, but it is thought that these may result from downhole reworking. 


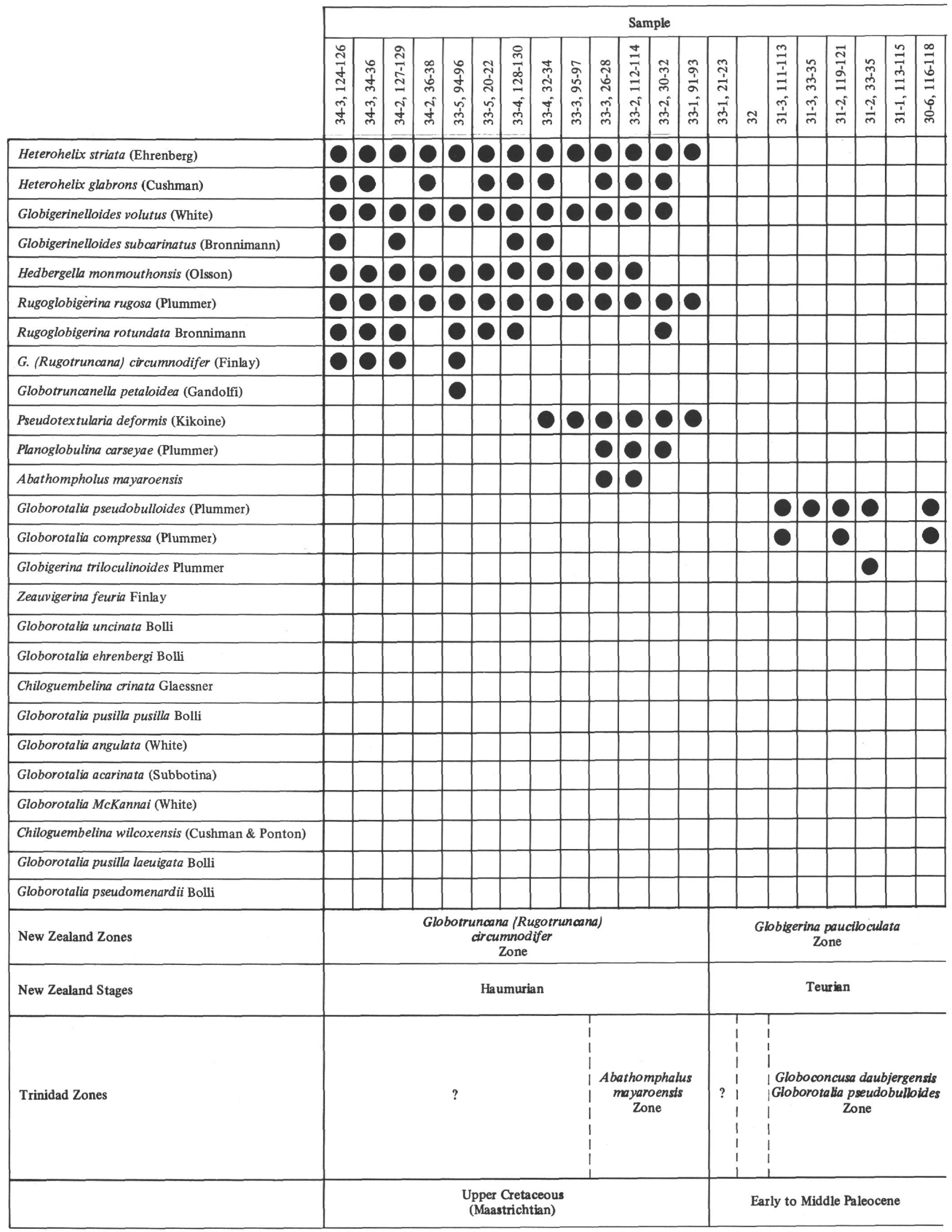

Figure 2. Stratigraphic distribution of planktonic foraminifera. 


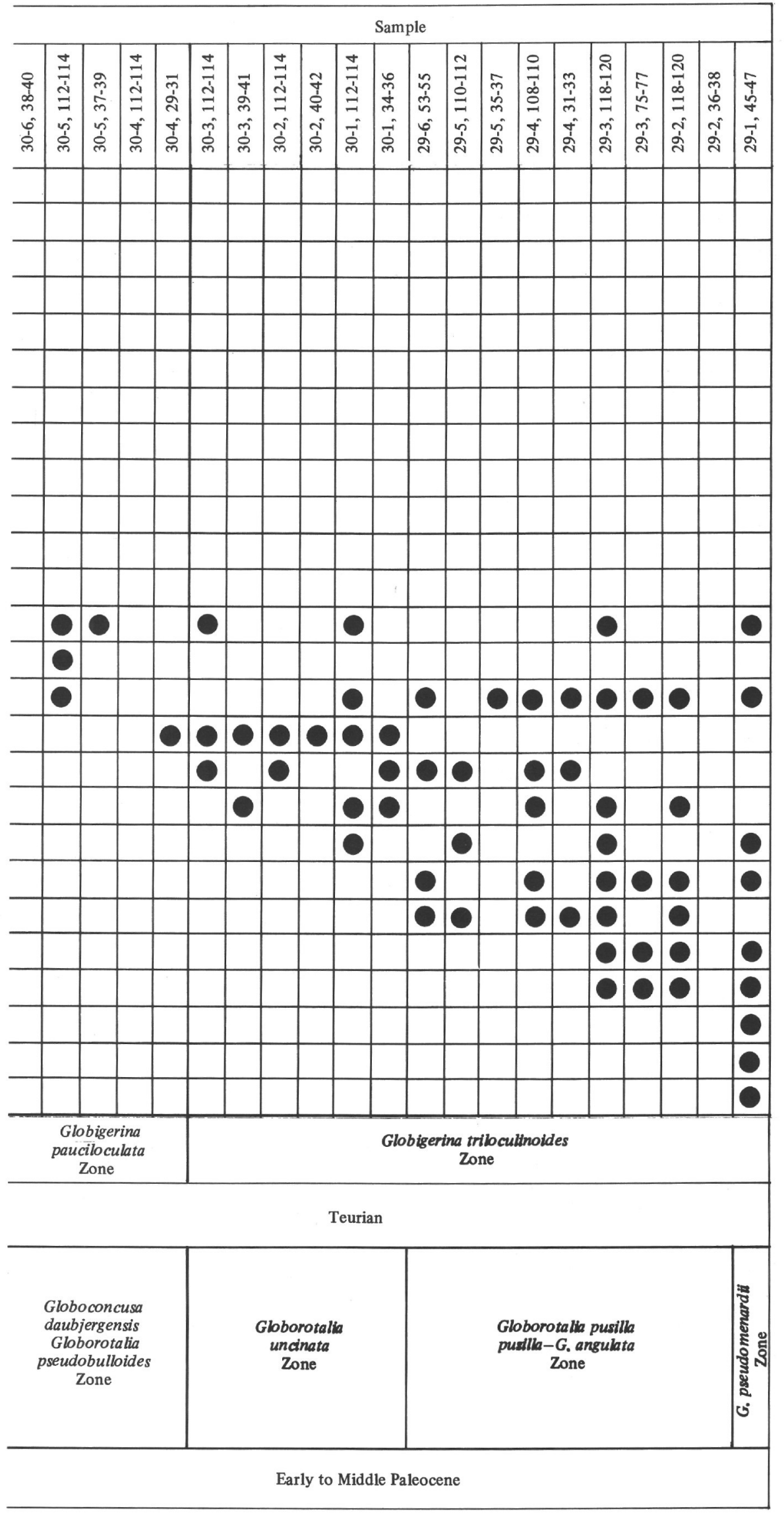

Figure 2. (Continued). 


\begin{tabular}{|c|c|c|c|c|c|c|c|c|c|c|c|c|c|c|c|}
\hline & \multicolumn{15}{|c|}{ Sample } \\
\hline & 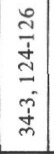 & $\begin{array}{l}0 \\
\stackrel{0}{0} \\
\dot{m} \\
\tilde{m} \\
\dot{m} \\
\dot{m}\end{array}$ & 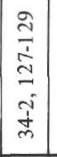 & $\begin{array}{c}\infty \\
0 \\
\tilde{b} \\
m \\
\tilde{y} \\
\dot{m}\end{array}$ & $\begin{array}{l}0 \\
\dot{q} \\
\dot{a} \\
\dot{n} \\
\tilde{m}\end{array}$ & 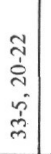 & 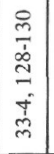 & $\begin{array}{l}\dot{m} \\
\tilde{u} \\
\tilde{n} \\
\dot{j} \\
\tilde{m}\end{array}$ & $\begin{array}{l}\hat{a} \\
\dot{s} \\
\hat{m} \\
\hat{m}\end{array}$ & 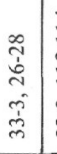 & 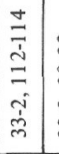 & 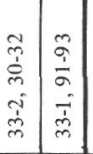 & $\begin{array}{l}\stackrel{m}{i} \\
\stackrel{\sim}{N} \\
\dot{m} \\
m\end{array}$ & $\begin{array}{l}\frac{m}{\bar{z}} \\
\underline{\Xi} \\
\frac{m}{m} \\
\frac{m}{m}\end{array}$ & $\begin{array}{l}n \\
m \\
m \\
m \\
m \\
\dot{m}\end{array}$ \\
\hline Dorothia biformis Finlay & 0 & 0 & & & 0 & & & & & & & 0 & & & \\
\hline Dorothia elongata Finlay & 0 & 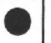 & & & 0 & & & 0 & 0 & O & & 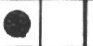 & & & \\
\hline Lenticulina (L.) insulsis (Cushman) & 0 & & & 0 & 0 & 0 & 0 & 0 & & 0 & 0 & 0 & & & \\
\hline Lenticulina (L.) macrodisca (Reuss) & 0 & 0 & 0 & 0 & 0 & 0 & 0 & 0 & 0 & & & - & & 0 & 0 \\
\hline Dentalina basiplanata Cushman & 0 & 0 & 0 & 0 & 0 & 0 & 0 & 0 & 0 & 0 & 2 & 0 & 0 & 0 & \\
\hline Nodosaria velascoensis Cushman & 0 & & 0 & 0 & & 0 & & 0 & & 0 & 0 & & & 0 & \\
\hline Nodosaria affinis Reuss & 0 & 0 & 0 & 0 & 0 & 0 & 0 & 0 & & 0 & & 0 & 0 & 0 & - \\
\hline Pseudonodosaria cylindracea (Reuss) & 0 & & & & & & & & & & & & & & \\
\hline Globulina lacrima Reuss & 0 & 0 & 0 & 0 & 0 & 0 & & 0 & & & & 0 & & 0 & \\
\hline Buliminella carseyae Plummer & 0 & 0 & & & & 0 & 0 & 0 & 0 & 0 & -18 & 010 & & & \\
\hline Bolivina incrassata Reuss & 0 & & 0 & 0 & 0 & 0 & 0 & 0 & 0 & ? & 0 & 0 & & 0 & \\
\hline Bolivinoides draco Marsson & 0 & 0 & 0 & 0 & 0 & 0 & 0 & 0 & 0 & 0 & 0 & 0 & & & \\
\hline Bolivinoides delicatulus Cushman & 0 & & & & & & & & & & & 0 & & & \\
\hline Bulimina rakauroana Finlay & 0 & 0 & 0 & 0 & 0 & 0 & 0 & 0 & & 0 & & 0 & & & \\
\hline Nuttallides florealis (White) & 0 & 0 & $\mathbf{O}$ & & 0 & 0 & 0 & 0 & & 0 & & 0 & & & \\
\hline Eponides bollii Cushman \& Renz & 0 & 0 & & 0 & & & & 0 & & & & 0 & & & \\
\hline Pleurostomella subnodosa Reuss & 0 & & & & & & & & & & & & & & \\
\hline Pullenia coryelli White & ? & & 0 & 0 & 0 & 0 & 0 & 0 & O & 0 & 0 & 0 & & 0 & 0 \\
\hline Alabamina creta (Finlay) & 0 & 0 & 0 & 0 & 0 & 0 & 0 & 0 & & 0 & & 0 & & 0 & 0 \\
\hline Osangularia navarroana Cushman & 0 & 0 & 0 & 0 & 1 & 0 & 0 & 0 & 0 & 0 & 0 & - & 0 & 0 & 0 \\
\hline Gyroidinoides globosus (Hagenow) & 0 & & 0 & & & 0 & & & & & & & & 0 & 0 \\
\hline Globorotalites sp. & 0 & 0 & 0 & 01 & 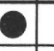 & & & 0 & & & 0 & 0 & & & \\
\hline Anomalinoides piripaua (Finlay) & 0 & 0 & 0 & 0 & 0 & 0 & 0 & 0 & - & 0 & 0 & 0 & 0 & 0 & 0 \\
\hline Anomalinoides rubiginosus (Cushman) & 0 & 0 & 0 & 0 & 0 & 0 & - & O & 0 & 0 & ? & 0 & 0 & & 0 \\
\hline Gavelinella beccarifformis (White) & 0 & 0 & 0 & 01 & 0 & 0 & 0 & 0 & 0 & 0 & 0 & 0 & 0 & 0 & 0 \\
\hline Gavelinella sp. & 0 & & & 0 & & & & 0 & & & & 0 & & & \\
\hline Cibicides stephensoni (Cushman) & 0 & & 0 & 0 & 0 & 0 & 0 & 0 & 0 & 0 & 0 & 0 & & & \\
\hline Ammodiscus cretaceus (Reuss) & & 0 & & & & & & & & & & 0 & & 0 & \\
\hline Glomaspira charoides (Jones \& Parker) & & 0 & & & 0 & & - & & 0 & & & & O & & \\
\hline Bolivinopsis spectobilis (Grzybowski) & & 0 & & & 0 & 0 & O & 0 & & 0 & & & & & \\
\hline Gaudryina healyi Finlay & & 0 & & & 0 & 0 & & & & & 0 & 0 & & & \\
\hline n. sp and gen. of Rzehakina & & 0 & 0 & & 0 & 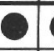 & 0 & & & & & & & & \\
\hline L. (Astacolus) cretacea (Cushman) & & 0 & 0 & & & & 0 & & 0 & 0 & & 0 & & & \\
\hline Nodosaria aspera Reuss & & 0 & & & & & & & & & & & & & \\
\hline Nodosaria limbata d'Orbgny & & 0 & & & & & & 0 & & & & & & & \\
\hline Nodosaria gracilitatis Cushman & & 0 & & & & & & & & & & & & & \\
\hline $\begin{array}{l}\text { New Zealand } \\
\text { Zones }\end{array}$ & & & & & $\begin{array}{r}\text { botru } \\
\text { circ }\end{array}$ & uncand & nodif & $\begin{array}{l}\text { ugotru } \\
\text { ier Zon }\end{array}$ & $\begin{array}{l}\text { uncone } \\
\text { ne }\end{array}$ & & & & & & \\
\hline $\begin{array}{l}\text { New Zealand } \\
\text { Stages }\end{array}$ & & & & & & & amuri: & & & & & & & & \\
\hline $\begin{array}{l}\text { Trinidad } \\
\text { Zones }\end{array}$ & & & & & $?$ & & & & & & $\begin{array}{r}\text { thomp } \\
\text { avaroe } \\
\text { Zone } \\
\end{array}$ & \begin{tabular}{l|}
$\begin{array}{l}\text { nphalus } \\
\text { oensis } \\
\text { ne }\end{array}$ \\
\end{tabular} & & & \\
\hline & & & & & & & & & & & & & & & \\
\hline
\end{tabular}

Figure 3. Stratigraphic distribution of benthic foraminifera. 


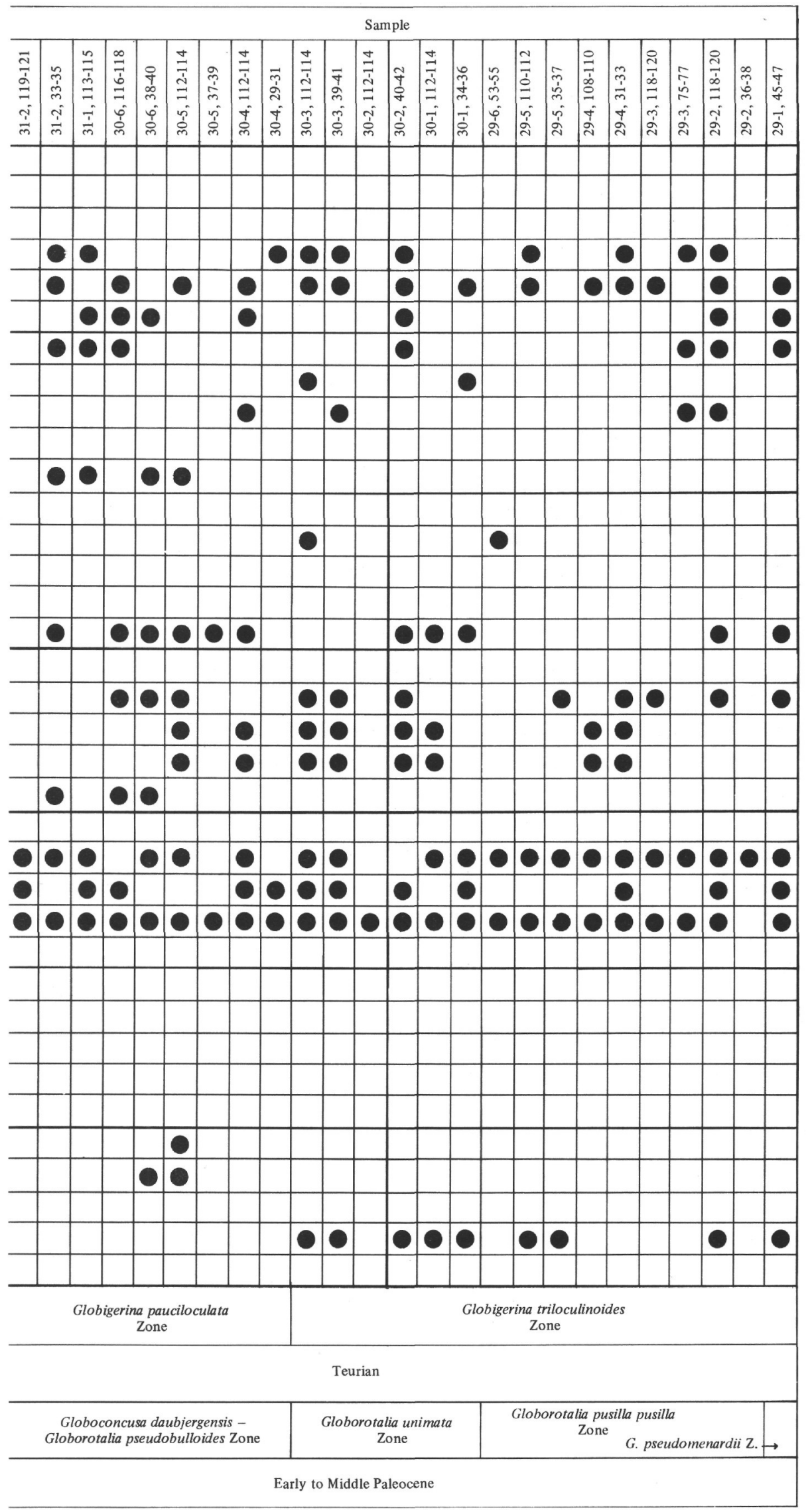

Figure 3. (Continued). 


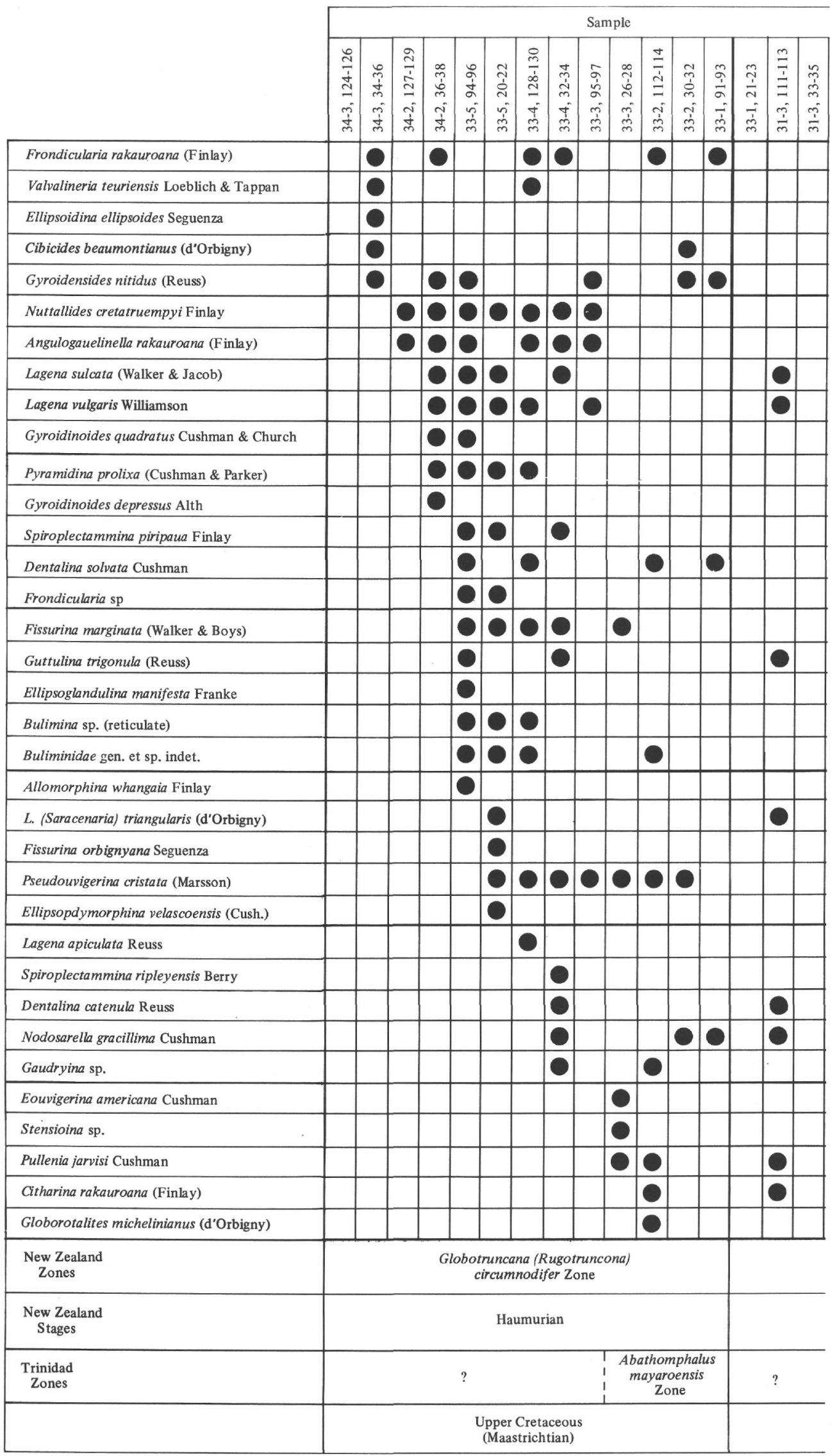

Figure 3. (Continued). 


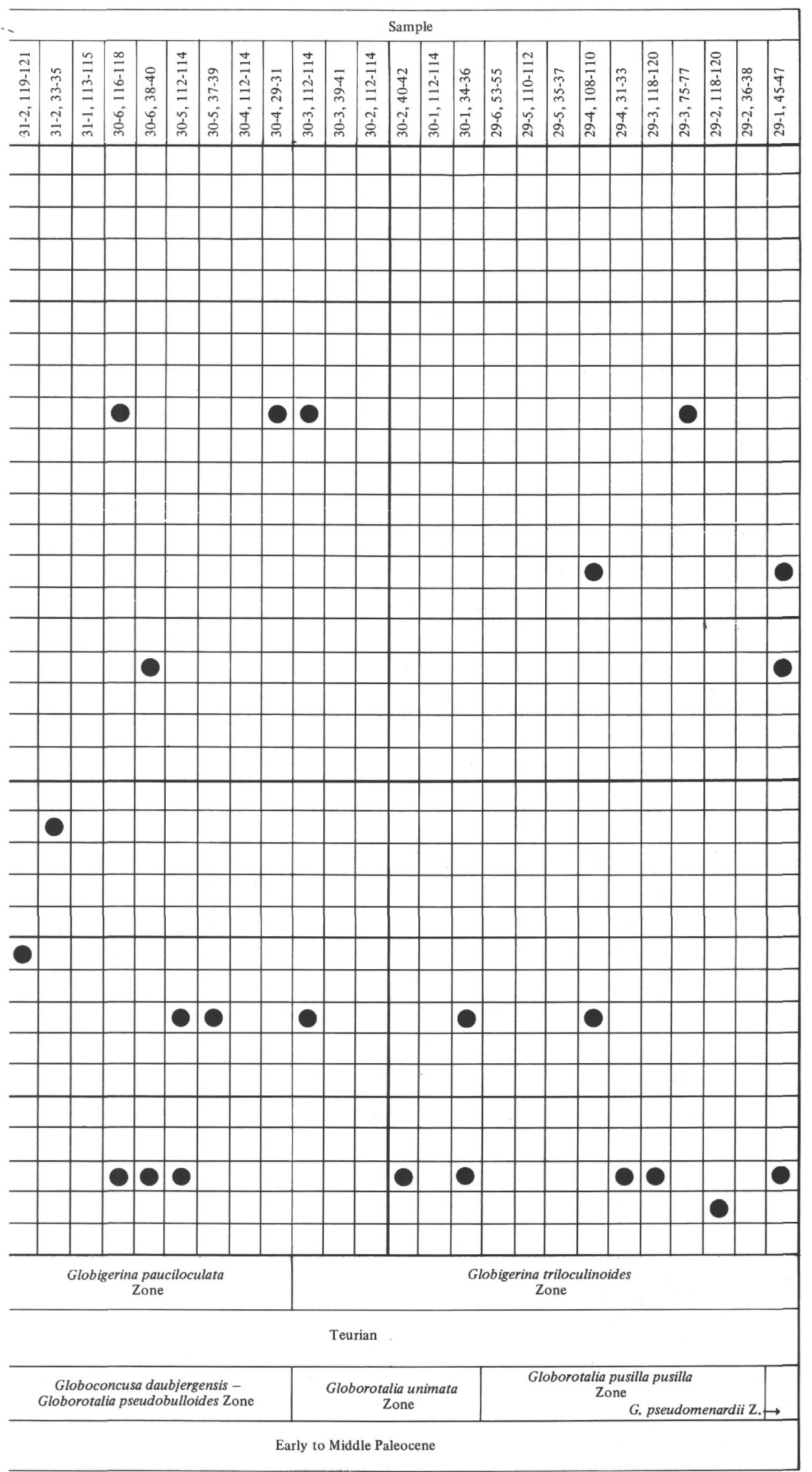

Figure 3. (Continued). 


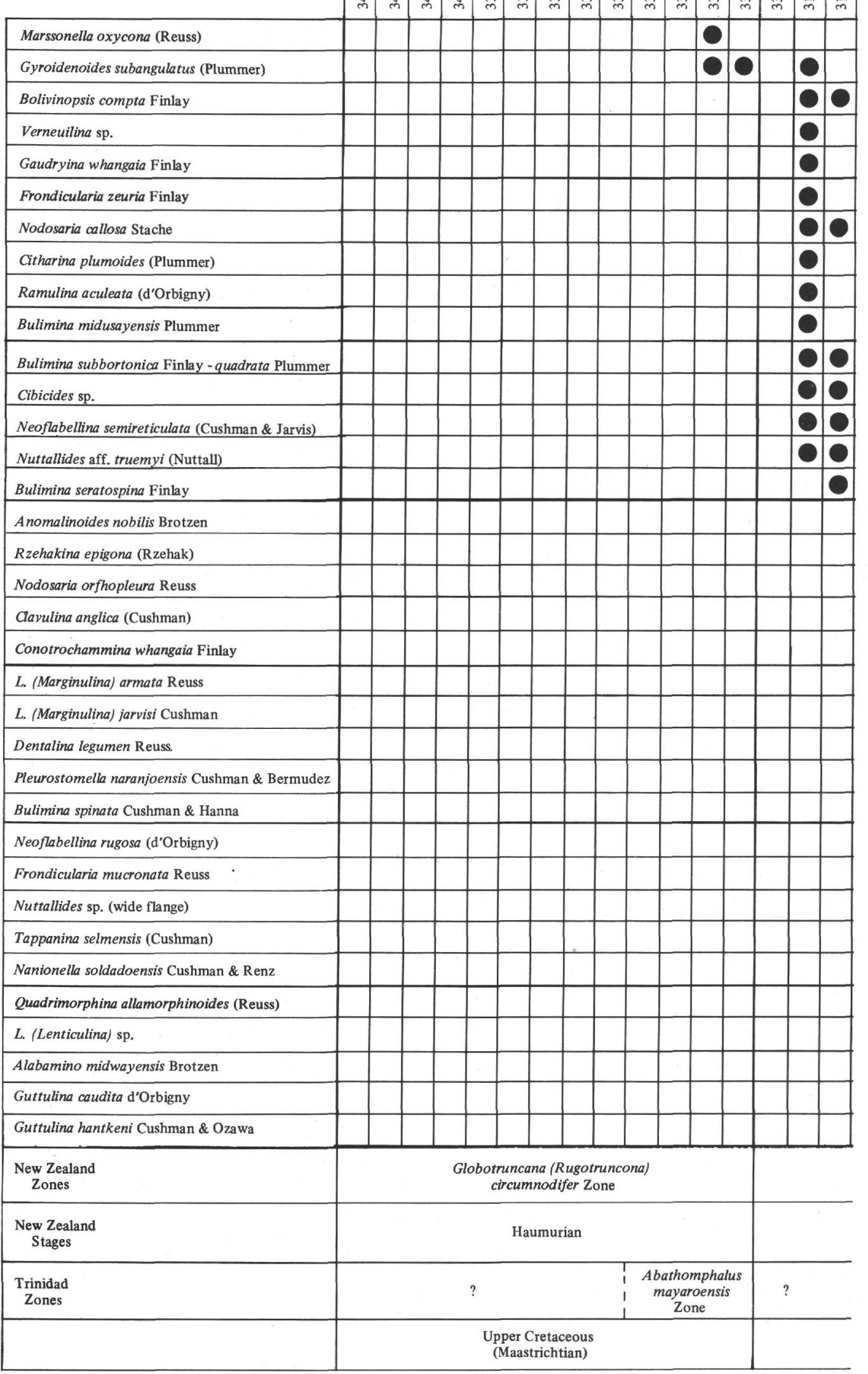

Figure 3. (Continued). 
Sample

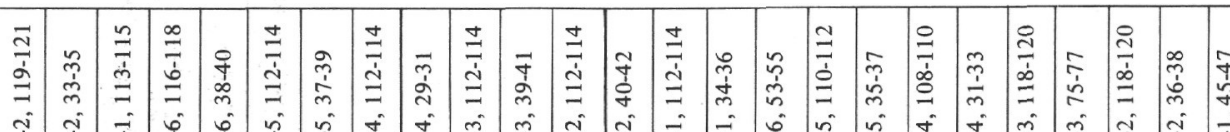

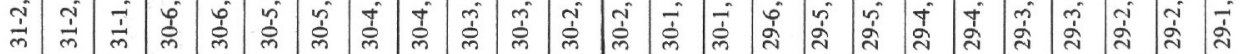

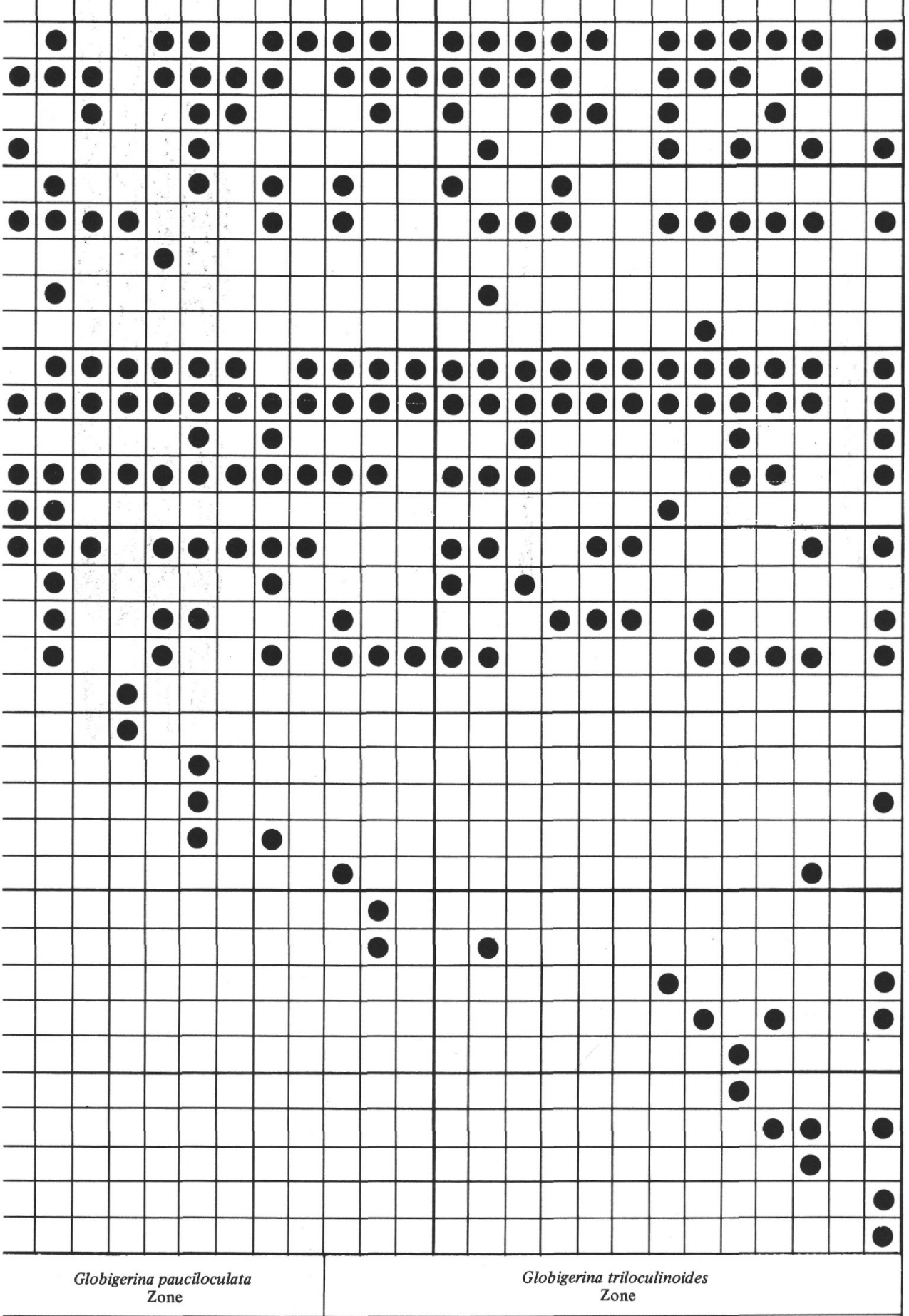

Teurian

Globoconcusa daubjergensis Globorotalia pseudobulloides Zone

Globorotalia unimata Zone

Globorotalia pusilla pusilla Zone

Figure 3. (Continued). 
Pseudotextularia deformis (Kikoine) (Plate 1, Figures 5-8).

Enters in Sample $33-4(32-34 \mathrm{~cm})$ and continues in abundance to the top of the Maestrichtian. Becomes the dominant taxon in the uppermost of the Maestrichtian samples. Tests are quite large with a robust widely spaced elongate ornament. Most tests have lost the last chamber. Its considerable abundance at Site 208 is in marked contrast to its record in New Zealand where only a single locality in Raukumara Peninsula is known.

\section{Planoglobulina carseyae (Plummer)} (Plate 1, Figure 9).

Present in low numbers in three samples in the uppermost part of the Maestrichtian succession where it occurs with Pseudotextularia deformis. Not known in the New Zealand Maestrichtian.

\section{Globigerinelloides volutus (White) (Plate 2, Figure 5-7).}

This is the second most abundant taxon in most Maestrichtian samples. The writer follows Pessagno (1967) in accepting $G$. volutus as a senior synonym of $G$. messinae Bronnimann. These specimens closely resemble New Zealand counterparts although the double end chambers and apertures were not encountered.

\section{Globigerinelloides subcarinatus (Bronnimann) (Plate 2, Figures 8-9).}

This tiny and distinctive species occurs sparsely in only four Maestrichtian sample. The end chambers normally are broken away.

\section{Hedbergella monmouthensis (Olsson)}

(Plate 3, Figures 1-2).

Present in low numbers in most samples. Reaches a peak in Sample $33-4(32-34 \mathrm{~cm})$ where it constitutes $2 \%$ of the fauna. The stratigraphically lower occurrences show no transition to Hedbergella holmdelensis Olsson, a species characteristic of the Middle and Lower Maestrichtian.

\section{Rugoglobigerina rugosa (Plummer) \\ (Plate 3, Figures 3-8).}

Normally the third or fourth most abundant taxon in most samples. Specimens show a considerable variation in the degree of ornamentation. Most show the typical heavy rugose ornament while a few are semi-rugose or even thin walled and pustulate. The latter resemble Rugoglobigerina pustulata Bronnimann.

\section{Rugoglobigerina rotundata Bronnimann (Plate 3, Figure 9).}

Present in much smaller numbers than $R$. rugosa. It is debatable whether this is a distinct species or a variant of $R$. rugosa. Certainly at Site 208, there is a distinct difference between the two species in chamber arrangement and size.

\section{Globotruncana (Rugotruncana) circumnodifer (Finlay) (Plate 4, Figures 1-4).}

Present in the four lowermost samples. This species has a distinctive four- to five-chambered test with heavy rugose ornament and strong paired keels. There is similarity to $R$. rugosa but the presence of strong paired keels make the distinction easy. First described from New Zealand where it occurs with $G$. (A.) mayaroensis Bolli. It is interesting to note, however, that at Site 208, the range of $G$. (R.) circumnodifer terminates prior to the appearance of $G$. (A.) mayaroensis. $G$. (R.) circumnodifer is obviously related to G. (R.) subcircumnodifier (Gandolfi) and other occurrences of Rugotruncana. A study of this group is currently under way.

\section{Globotruncanella petaloidea (Gandolfi)}

A single specimen is present in Sample 33-5(94-96 cm). This is the first record of the species from the southwest Pacific area.

\section{Globotruncana (Abathomphalus) mayaroensis Bolli} (Plate 4, Figures 7-9).

Occurrs only near the top of the Maestrichtian succession in Samples 33-2(112-114 cm) and 33-3(26-28 $\mathrm{cm})$. Extremely rare with only about fifteen tests being recovered from these two samples. Identical in size and morphology to specimens in the Whangai and Rakauroa Formations (Webb, 1971). The related G. (A.) intermedia Bolli is present in Northland, New Zealand (Webb, 1971), but has not been seen in the Lord Howe Rise material.

\section{Globigerina triloculinoides Plummer (Plate 5, Figures 4-5).}

This species is not particularly common but tends to increase in abundance towards the upper part of the Paleocene succession.

\section{Globorotalia pseudobulloides (Plummer)}

(Plate 5, Figures 1-2).

Most common in the lower part of the Paleocene, particularly in Sample 30-5(112-114 cm) where it makes up $18 \%$ of the total fauna.

\section{Globorotalia uncinata Bolli}

(Plate 6, Figures 1-3)

Appears first in Sample 30-3(112-114 cm) but further sampling might extend its entry slightly lower. This species exhibits some variation in outline but satisfies the diagnosis in possessing a flat or slightly convex spiral side with curved and slightly depressed sutures and a more strongly convex umbilical side with radial and more depressed sutures. Umbilicus narrow, deep, and open. Outline subacute in side view. Aperture elongate interio-marginal extra-umbilical to umbilical. Final chamber frequently broken away. Reticulate ornament, slightly coarser than for G. pseudobulloides and $G$. triloculinoides. Also present in $G$. pusilla pusilla-G. angulata Zone. Not reported as yet from New Zealand.

\section{Globorotalia angulata (White) \\ (Plate 6, Figures 4, 7).}

Appears first in Sample 29-6(53-55 cm) and present in low numbers throughout the $G$. pusilla pusilla- $G$. angulata Zone. Not continuing into $G$. pseudomenardii Zone. Transitional forms between $G$. uncinata and $G$. angulata are present (Plate 6, Figure 4). Globorotalia angulata is never as 
acutely angled as in Bolli (1957, pl. 17, figs. 7-9), but is closer to those shown in his plate 17, figures 10-12. Spiral side flat with strongly recurved, slightly depressed sutures, ubilical side strongly convex with radial strongly depressed sutures. Umbilicus narrow and deep. The occurrence at Site 208 appears earlier than in New Zealand where Jenkins (1971) reports it in Late Paleocene post-Teurian (i.e. Waipawan) sediments.

\section{Globorotalia compressa (Plummer)}

Restricted to the lower part of the Paleocene succession ( $G$. daubjergensis-G. pseudobulloides Zone). Tests very small and final chamber frequently broken away.

\section{Globorotalia ehrenbergi Bolli \\ (Plate 5, Figure 6).}

Appears first in G. uncinata Zone, Sample 30-3(39-41 $\mathrm{cm}$ ), and ranges up to the top of the G. pusilla pusilla-G. angulata Zone. Test larger than the preceding Globorotalia compressa. The two species do not overlap at Site 208. It precedes $G$. pseudomenardii and again the two species do not overlap. Periphery acute but not keeled. Final chamber often broken away. Not reported by Jenkins (1971) from New Zealand.

\section{Globorotalia pseudomenardii Bolli (Plate 5, Figures 7-9).}

Occurs abundantly in the uppermost of the Paleocene samples, 29-1(45-47 cm). Periphery strongly acute and with a distinct keel. Chambers strongly compressed. Final chamber frequently broken away.

\section{Globorotalia acarinata (Subbotina)}

(Plate 6, Figure 9).

Appears high in the G. pusilla pusilla-G. angulata Zone in Sample 29-3 $(118-120 \mathrm{~cm})$ and continues into the $G$. pseudomenardii Zone where it is the dominant taxon.

\section{Globorotalia mckannai (White)}

Appears at the same level as G. acarinata and ranges up into the G. pseudomenardii Zone.

\section{Globorotalia pusilla pusilla Bolli}

Appears first in Sample 29-6(53-55 cm) with G. angulata and ranges up into the $G$. pseudomenardii Zone. Uncommon. Small, early circular tests with a subacute outline in side view. Strongly curved sutures on the spiral side with sutures slightly depressed, particularly in the final whorl. A small narrow umbilicus.

\section{Globorotalia pusilla laevigata Bolli}

A few tests enter along with $G$. pseudomenardii in Sample 29-1(45-47 cm).

\section{STRUCTURE OF FORAMINIFERAL POPULATIONS}

An attempt is made to record the structure of individual populations by census counts and species diversity determinations. As pointed out in the introductory section, bioturbation structures are common throughout this Maestrichtian-Paleocene section and populations have probably been reorganized to some unknown degree. This factor has been ignored in the present study.

\section{Census Studies}

The residue resulting from the washing to $10 \mathrm{cc}$ of core was reduced to a much smaller quantity by microsplitter. This residue was spread on a squared counting tray and species determinations made for 300 randomly selected specimens. Only species with counts of five or more were recorded in the histograms shown in Figures 4 and 5. Information from each sample is summarized in Figure 6 where data is reduced to percentage form and portrayed in stratigraphic order. The first column shows the proportion of planktonic to benthic taxa, while the second and third columns provide the percentages for the dominant benthic and planktonic taxa. Maestrichtian samples are particularly rich and lend themselves readily to this treatment. Only five of the Paleocene samples were rich enough to be subjected to census studies.

Maestrichtian samples reveal that, in almost every case, planktonic taxa constitute more than 75 to $80 \%$ of the faunas (Figure 4). Heterohelix striata (Ehrenberg) is by far the most dominant taxon, making up between $31 \%$ and $53 \%$ of the faunas. (Figure 6). Low in the Maestrichtian succession, Globigerinelloides volutus (White) and Rugoglobigerina rugosa (Plummer) are the next most abundant taxa. Towards the top of the Maestrichtian, Pseudotextularia deformis (Kikoine) becomes increasingly prolific and, in the uppermost sample $(33-2,30-32 \mathrm{~cm})$, it is the dominant species. Gavelinella beccariiformis (White) is the dominant benthic taxon throughout the Maestrichtian but never achieves an abundance greater than $12 \%$. It may be significant that low in the Maestrichtian succession, the percentage occurrence of $G$. beccariiformis increases slightly while the percentage for $H$. striata is slightly lower (Figure 6). Census data on Maestrichtian sediments indicate the existence of a high degree of population stability.

Much greater variability characterizes the Paleocene succession. A sample from the $G$. daubjergensis- $G$. pseudobulloides Zone $(31-2,33-35 \mathrm{~cm})$ contains no planktonic taxa but a rich assemblage of benthic taxa. Gavelinella beccariiformis (White) attains its greatest abundance for the entire section at 33\% of the fauna (Figures 5 and 6). Other prominent taxa include Cibicides sp., Anomalinoides piripaua (Finlay), Nodosaria velascoensis Cushman, Gyroidinoides subangulatus (Plummer), G. globosus (Hagenow), and Nuttallides aff. truempyi (Nuttall), in that order.

Slightly higher in the same zone (Sample 31-2, 33-35 $\mathrm{cm})$, planktonics are present but the most abundant, $G$. pseudobulloides (Plummer), constitutes only 5\% of the fauna. Here, Nuttallides aff. truempyi (Nuttall) is the dominant taxon, making up 19\% of the fauna (Figures 5 and 6), and is closely followed by Bulimina serratospina Finlay, Cibicides sp., Bolivinopsis compta Finlay, Gavelinella beccariiformis (White), Anomalinoides piripaura (Finlay), Bulimina subbortonica Finlay-quadrata Plummer, Gyroidinoides subangulatus (Plummer), G. globosus (Hagenow), and Pullenia coryelli White.

Higher in the G. daubjergensis-G. pseudobulloides Zone (Sample 30-5, 112-114 cm), planktonic taxa increase markedly to constitute $52 \%$ of the fauna, with Globorotalia pseudobulloides (Plummer) dominant at $18 \%$, followed by Globorotalia compressa (Plummer) at 13\%. Here, the dominant benthic is Nuttallides aff. truempyi (Nuttall), also 


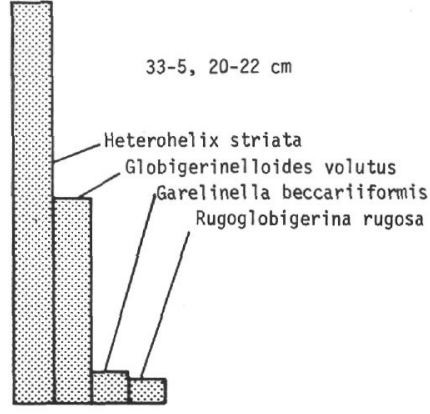

$\uparrow$

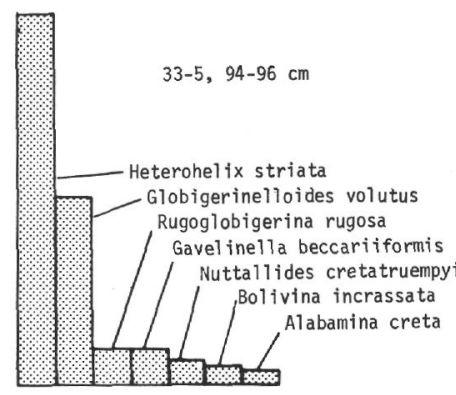

4

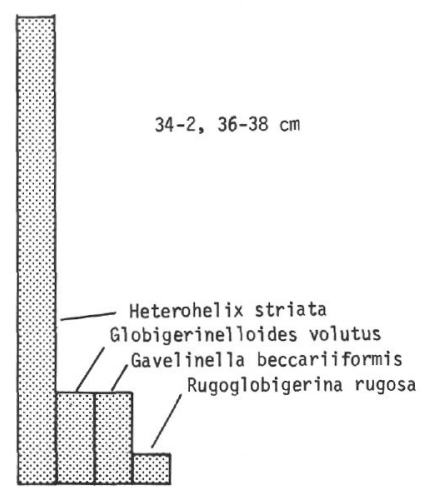

4

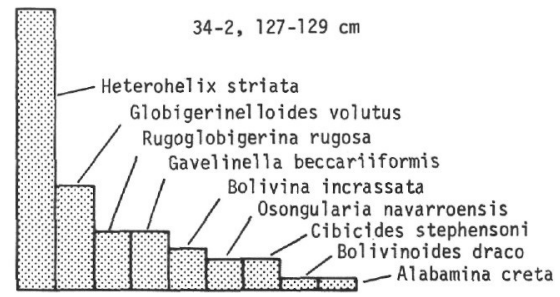

\section{4}

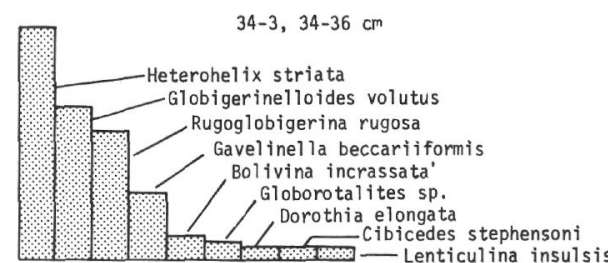

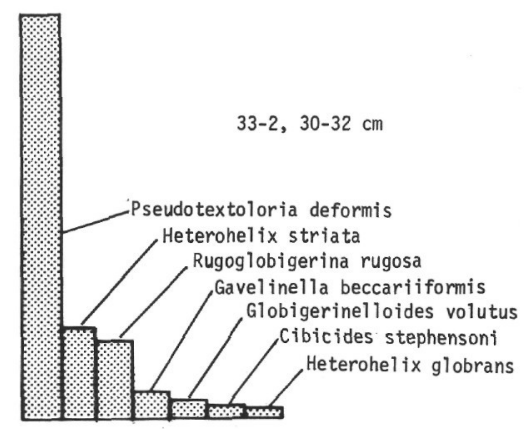

4

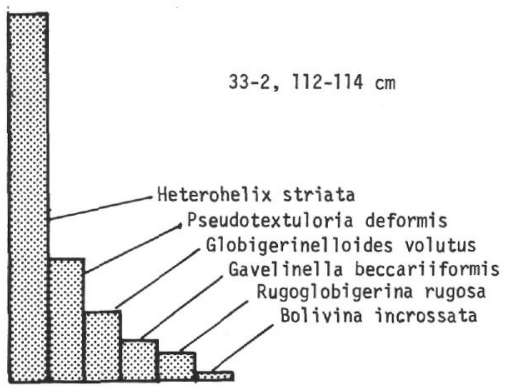

4
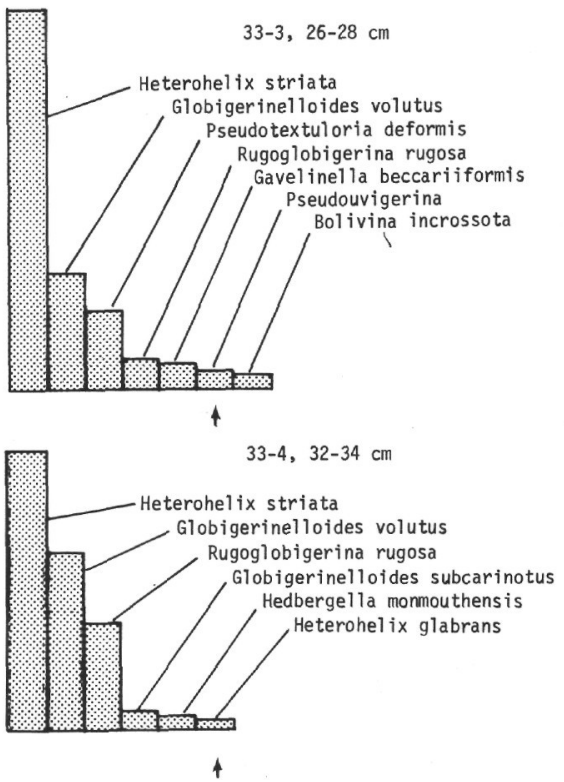

$33-4,128-130 \mathrm{~cm}$

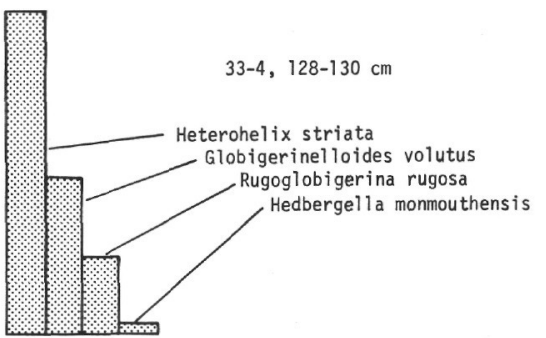

Figure 4. Census histograms of ten Maestrichtian faunas. Based on 300 counts of randomly selected foraminifera. Species with counts of less than five are excluded. 
$29-2,36-38 \mathrm{~cm}$

Globorotalia acarinata

Globigerina triloculinoides

Globoratalia mckannoi

Govelinella beccariiformis

Globorotalia pseudobulloides Globorotalia pseudomenardi Bullimina subbortonica-quadrata

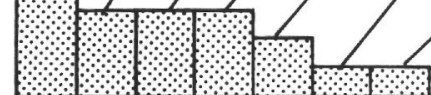

$31-2,33-35 \mathrm{~cm}$

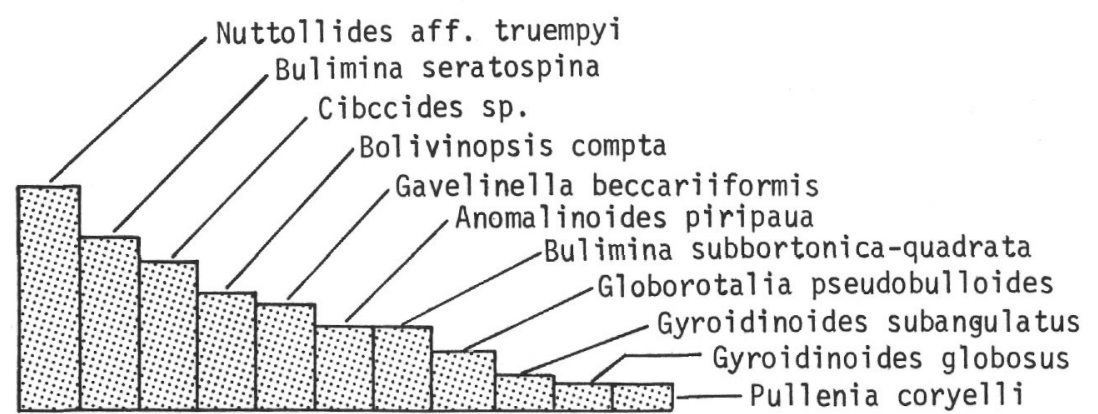

Figure 5. Census histograms of five Paleocene faunas. Based on 300 counts of randomly selected foraminifera. Species with counts of less than five are excluded.
Cibicides sp.

Gyroidinoides subangulatus $\quad 30-3,112-114 \mathrm{~cm}$

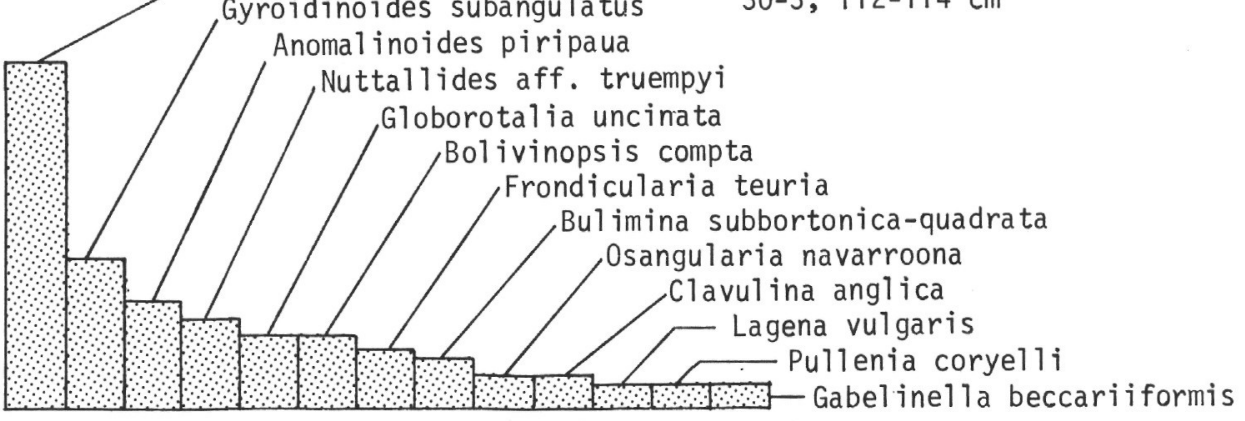

208-30-5, $112-114 \mathrm{~cm}$

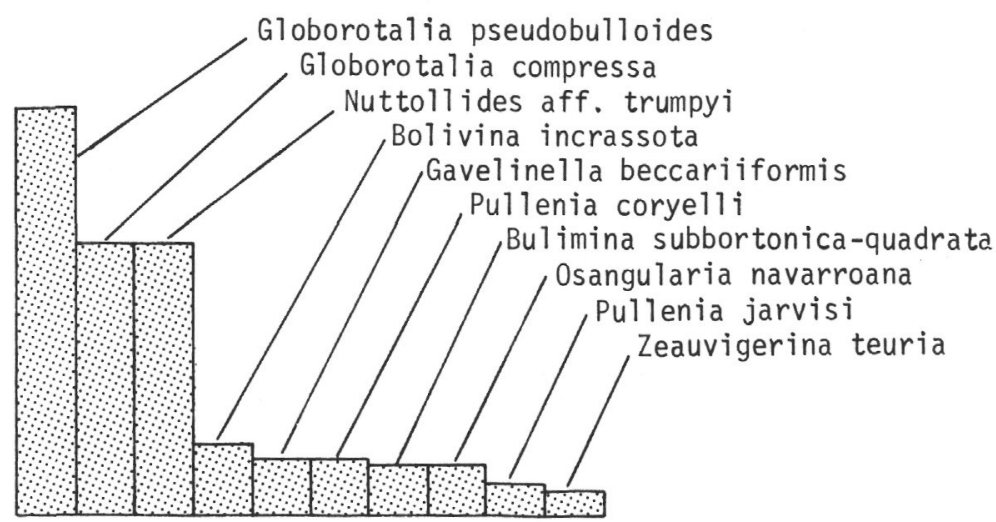

208-31-3, 111-113 cm

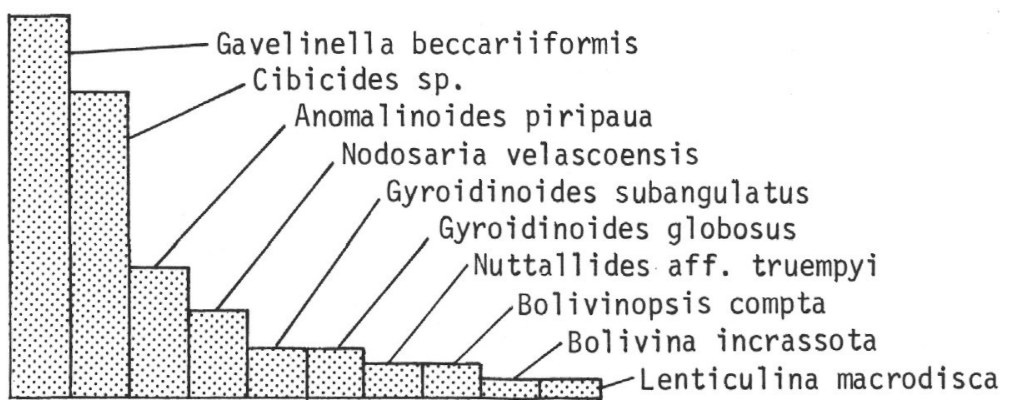




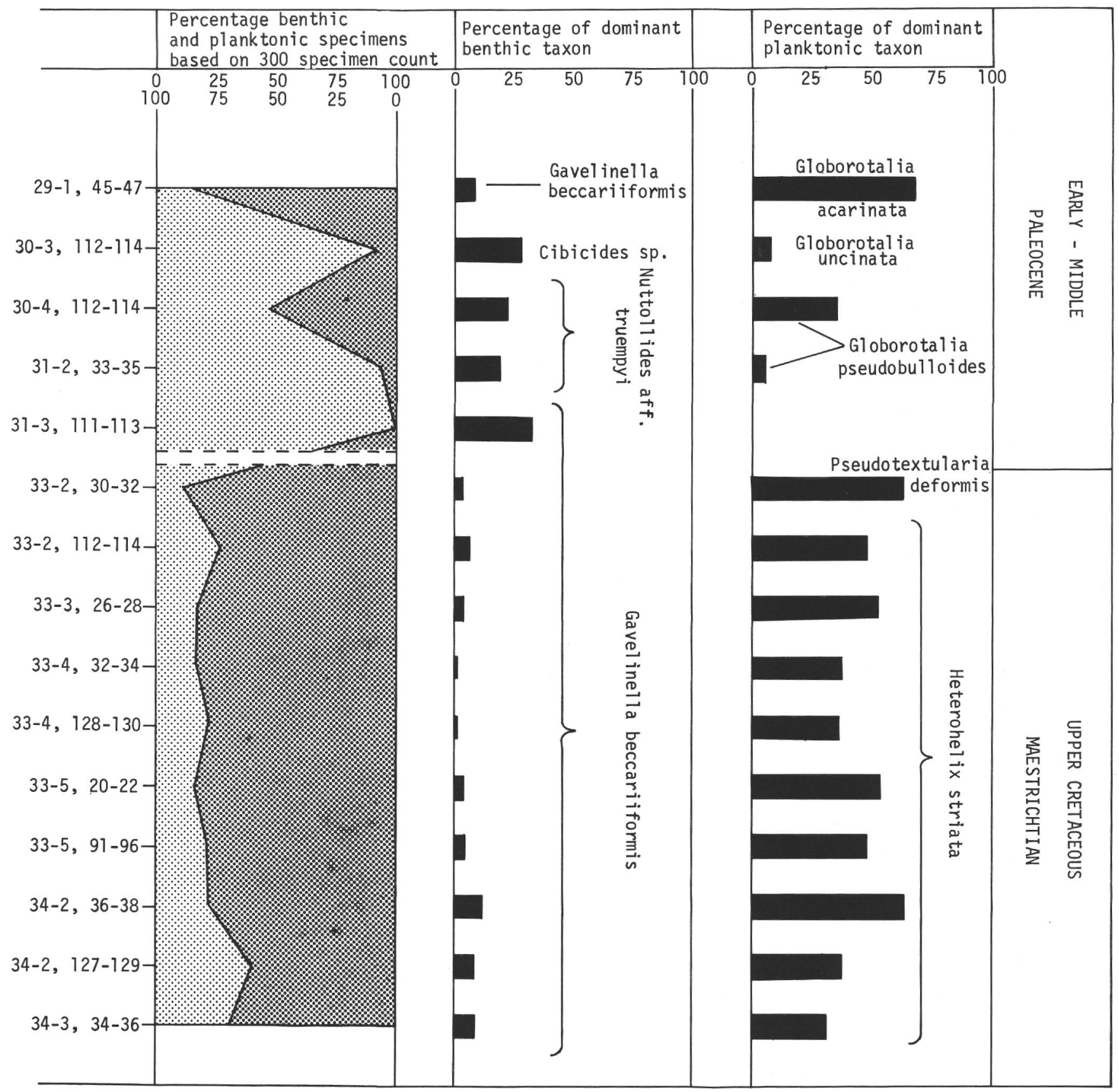

Figure 6. Information shown is based on census histograms (Figures 4 and 5). Data is based on 300 counts and reduced to percentage form. First column shows proportion of benthic to planktonic taxa. Center and right hand columns show the dominant benthic and planktonic taxa and their percentage occurrence.

at $13 \%$. Benthic species making up between $2 \%$ and $6 \%$ of the fauna included Bolivina incrassata (Reuss), Gavelinella beccariiformis (White), Pullenia coryelli White, Bulimina subbortonica Finlay-quadrata Plummer, Osangularia navarroana (Cushman), and Pullenia jarvisi Cushman, in that order.

Sample 30-3, 112-114 cm, from low in the G. uncinata Zone, is dominated by benthics (94\%) (Figures 5 and 6). Cibicides sp. is clearly the most dominant taxon $(22 \%)$ with Gyroidinoides subangulatus (Plummer), Anomalinoides piripaua (Finlay), Nuttallides aff. truempyi (Nuttall), Bolivinopsis compta Finlay, Frondicularia teuria Finlay,
Bulimina subbortonica Finlay-quadrata Plummer, Osangularia navarroana Cushman, Clavulina anglica (Cushman), Lagena vulgaris Williamson, Pullenia coryelli White, and Gavelinella beccariiformis, in that order, constituting between $12 \%$ and $2 \%$ of the total fauna. G. uncinata Bolli is the dominant planktonic taxon but makes up only $5 \%$ of the fauna.

The uppermost sample $(29-1,45-47 \mathrm{~cm}$ ) (lowermost $G$. pseudomenardii Zone) shows a major shift in the proportions of planktonic and benthic taxa. Planktonic taxa constitute $85 \%$ of the total fauna, a figure common to the Maestrichtian faunas below (Figures 5 and 6). 
Globorotalia acarinata (Subbotina) is the dominant taxon at $68 \%$ with Globigerina triloculinoides Plummer and Globorotalia mckannai (White) both constituting 7\% of the fauna. The important zone fossil Globorotalia pseudomenardii Bolli makes up only $2 \%$ of the fauna. The dominant benthic taxon is Gavelinella beccariiformis (White) at $7 \%$.

In conclusion, two further points emerge from this census study. First, agglutinated taxa play almost no part in the histograms of Maestrichtian and Paleocene faunas (Figures 4 and 5). In the Maestrichtian, no agglutinated benthic constitutes more than $2 \%$ of the total fauna, while in the Paleocene only Bolivinopsis compta Finlay and Clavulina anglica (Cushman) appear in the histograms (Figure 5). The former makes up 10\% of one population and the latter only $3 \%$ of another population. The second point is that important stage and zone taxa exhibit very low abundances, often less than $2 \%$ of the total fauna. These include such important taxa as Gaudryina healyi Finlay, Dorothia elongata Finlay, Frondicularia rakauroana (Finlay), Bolvinoides draco Marsson, Globotruncana (Rugotruncana) circumnodifer (Finlay), and Globotruncana (Abathomphalus) mayaroensis Bolli in the Maestrichtian and Gaudryina whangaia Finlay, Clavulina anglica (Cushman), Conotrochammina whangaia Finlay, Frondicularia teuria Finlay, Neoflabellina semireticulata (Cushman and Jarvis), N. rugosa (d'Orbigny), Globorotalia angulata Bolli, and G. pseudomenardii Bolli in the Paleocene.

The benthic taxa named here are much more abundant in the New Zealand Maestrichtian and Paleocene. In most cases, the diagnostic planktonic taxa occur with about the same rarity as their counterparts in New Zealand. Davids (1966) has provided census counts on Maestrichtian planktonics in Trinidad and other areas which indicate that important taxa such as Globotruncana (Abathomphalus) mayaroensis Bolli are also rare in low-latitude areas. His studies of similar Maestrichtian sediments from the Gulf-Caribbean-eastern North America area also show that planktonics are dominant and that Heterohelicidae dominate the planktonic taxa, followed by Globigerinelloides and Rugoglobigerina. Unfortunately, such census data is not available for low-latitude Paleocene populations and it would be interesting to know if the diagnostic Paleocene planktonics named above are also present in such low quantities as in the Site 208 populations. Another point, as yet unexplained, is the extreme rarity of Chiloguembelina in the Paleocene at Site 208, in sharp contrast to the overwhelming abundance of Heterohelix in the underlying Maestrichtian.

\section{Species Diversity Studies}

Counts of the total number of species per sample (in 10 $\mathrm{cc}$ washed samples) reinforces the rule that low diversity is generally accompanied by high dominance. For the Maestrichtian, it may be seen (Figures 6 and 7) that although there are only 12 species of planktonic foraminifera present, they commonly make up 75 to $80 \%$ of the fauna in terms of test counts. The calcareous benthic species are relatively diverse at 62 species yet constitute only 15 to $20 \%$ of the fauna. None of the 11 species of Maestrichtian agglutinated foraminifera constitute more than 1 to $2 \%$ of the fauna. Species diversity for agglutinated taxa is very stable through the Maestrichtian and Paleocene and seldom rises above three or four for any one sample (Figure 7). There is a tendency for one or two samples low in the Maestrichtian succession to have as many as eight agglutinated taxa. The number of calcareous benthic taxa shows a slight decrease towards the top of the Maestrichtian, followed by a sharp increase at the base of the Paleocene succession and a further slight decrease higher in the section. One characteristic of the Paleocene calcareous benthic taxa is the considerable fluctuation in species numbers, perhaps reflecting instability in the bottom environment. Planktonic diversity shows a steady increase up the Paleocene succession. The marked contrast in diversity of planktonics across the MaestrichtianPaleocene boundary is striking (Figure 7).

\section{CRETACEOUS-TERTIARY BOUNDARY}

The major change occurring across the MaestrichtianPaleocene boundary at Site 208 is already apparent from the foregoing discussion and is obvious in Figures 6 and 7. Census studies have shown a major shift in the proportions of planktonic and benthic groups across this boundary, i.e., $12 \%$ benthic content in Maestrichtian Sample 33-2, 30.32 $\mathrm{cm}$ to $100 \%$ in the Early Paleocene Sample 31-2, 111-113 $\mathrm{cm}$. Ecological changes occurring across this boundary involved a massive increase in productivity among the benthic groups whereas planktonic groups suffered total destruction followed by progressive revival. Calcareous benthics in some lower samples, particularly 33-1, 21-23 $\mathrm{cm}$, are poorly preserved and commonly broken. They are accompanied by abundant fish teeth and sponge spicules. There is no indication of Maestrichtian taxa reworked into the Paleocene. The importance of this particular boundary is made clearer when we consider the level of extinction of the three main foraminiferal groups. This information is provided in Figures 2 and 3 and has been summarized in Figure 8 . These figures show that there has been extinction of $100 \%$ of planktonics, $52 \%$ of calcareous benthics, and 73\% of agglutinated benthics across the MaestrichtianPaleocene boundary at Site 208. This provides an average of $62 \%$ extinction for the entire fauna. Extinction figures for Trinidad, extracted from several sources, are also shown in Figure 8 . Here the extinction for all groups is only $27 \%$. This difference is striking and could be explained in two ways. First, Maestrichtian-Paleocene faunas of Trinidad might represent shallower inshore sites of deposition. Under such conditions, benthic taxa would have a higher tolerance to environmental changes brought about by hydrological or tectonic influences and tend to range through the Maestrichtian-Paleocene boundary. Second, the low-latitude and warmer-water Trinidad faunas may have experienced little climatic fluctuation across the boundary and a resulting low incidence of extinction among the benthic community. In the southwest Pacific (Site 208), the transition from Maestrichtian to Paleocene may have been marked by a distinct drop in temperature and so account for the very high extinction rate among benthic taxa. These suggestions do not explain the one hundred percent extinction common to planktonic taxa in both the 


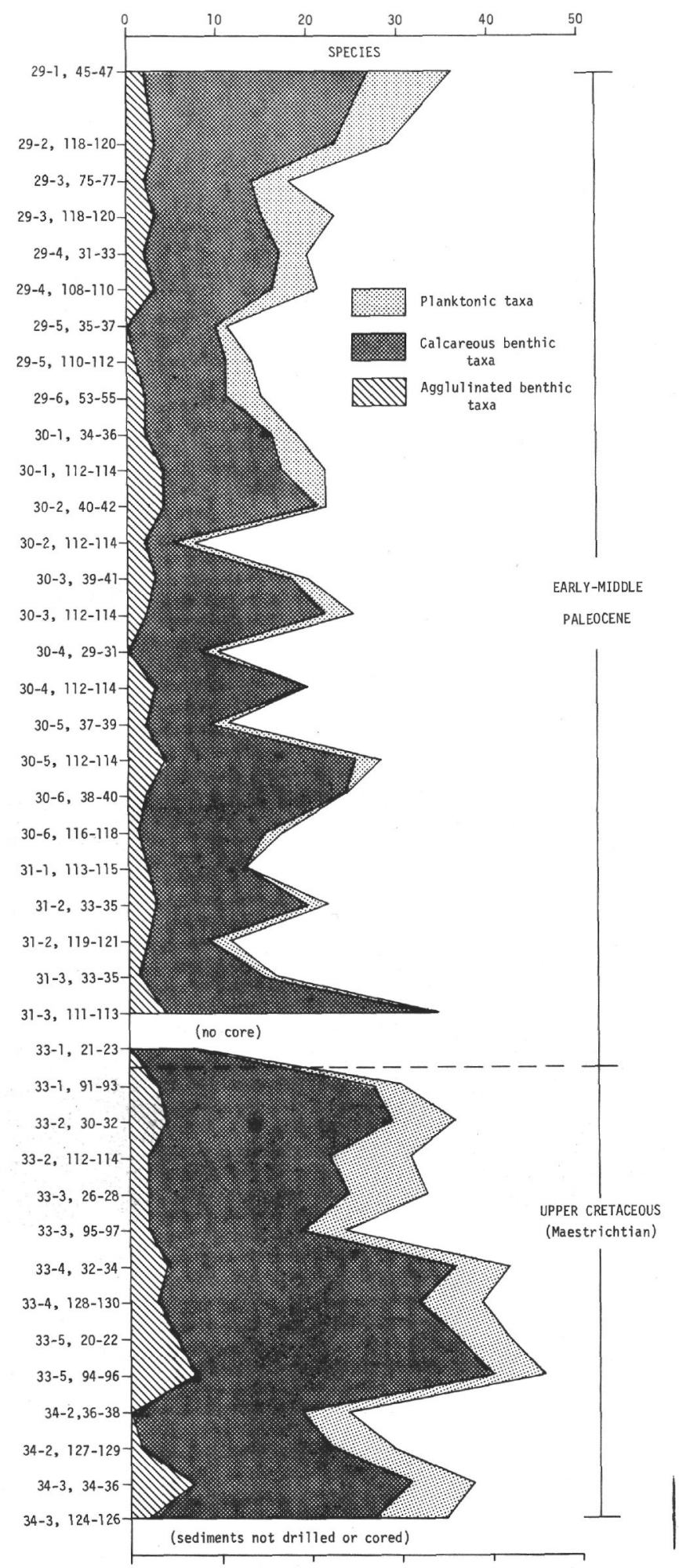

Figure 7. Species diversity for all Maestrichtian and Paleocene samples, showing numbers of agglutinated and calcareous benthic and planktonic taxa extracted after exhaustive picking of a 10-cc sample retained on screen of 200 mesh. low-latitude Trinidad and higher-latitude Lord Howe Rise faunas.

A disconformity, or at least a hiatus, separates the Maestrichtian and Paleocene at Site 208. The writer suggests that, following warm to temperate, relatively deep water conditions in the Maestrichtian, there was an elevation of Maestrichtian sediments or a drop in sea level, or both, before the onset of Paleocene sedimentation. Early Paleocene faunas suggest shallower and perhaps cooler conditions. By the mid-Paleocene, water depths had increased and the abundance of planktonic taxa suggests a return to warmer conditions similar to those prevailing during the Maestrichtian.

\section{CONCLUDING REMARKS}

From the present study, it may be seen that drilling at Site 208 terminated in Maestrichtian pelagic chalks. The age of the oldest marine sediments in this part of the Lord Howe Rise remains unanswered. Population census counts and diversity counts show that Maestrichtian foraminiferal faunas maintain a high degree of stability to the base of the cored section. There is, therefore, no suggestion that environments of deposition are shallowing downward and it seems reasonable to predict that Campanian, or even older marine sediments, are present lower in the sedimentary column of the Lord Howe Rise. This can only be tested by further drilling.

\section{ACKNOWLEDGMENTS}

The writer wishes to thank the Deep Sea Drilling Project and especially the paleontologists of Leg 21 for making this material available for study. Miss Mary Jennings prepared SEM prints and Mr. R. C. Brazier and Mr. B. J. Burt assisted with the preparation of the plates. Scanning Electron Microscope photographs were made by the author on a Cambridge Mark II instrument at the Physics and Engineering Laboratory, Department of Scientific and Industrial Research, Gracefield, Lower Hutt.

\section{REFERENCES}

Beckmann, J. P., 1957. Chiloguembelina Loeblich and Tappan and related foraminifera from the lower Tertiary of Trinidad, B.W.I. Bull. U.S. Nat. Mus., v. 215, p. 83. 1960. Distribution of benthonic foraminifera at the Cretaceous-Tertiary boundary of Trinidad (West Indies). International Geological Congress, XXI Session, Norden, 1960, Part V, The Cretaceous-Tertiary Boundary. p. 57.

Bolli, H. M., 1957. The genera Globigerina and Globorotalia in the Paleocene-lower Eocene Lizard Springs Formation of Trinidad, B.W.I. Bull. U.S. Nat. Mus., v. 215, 61 . 1966. Zonation of Cretaceous to Pliocene marine sediments based on planktonic foraminifera. Boletin Informativo, Asociacion Venezolana de Geologia, Minera y Petroleo. v. 9, no. 1, p. 3.

Davids, R. N., 1966. A Paleoecologic and Paleo-biogeographic study of Maastrichtian planktonic foraminifera. Ph.D. thesis, Rutgers State University, New Brunswick, New Jersey. 241 p. 


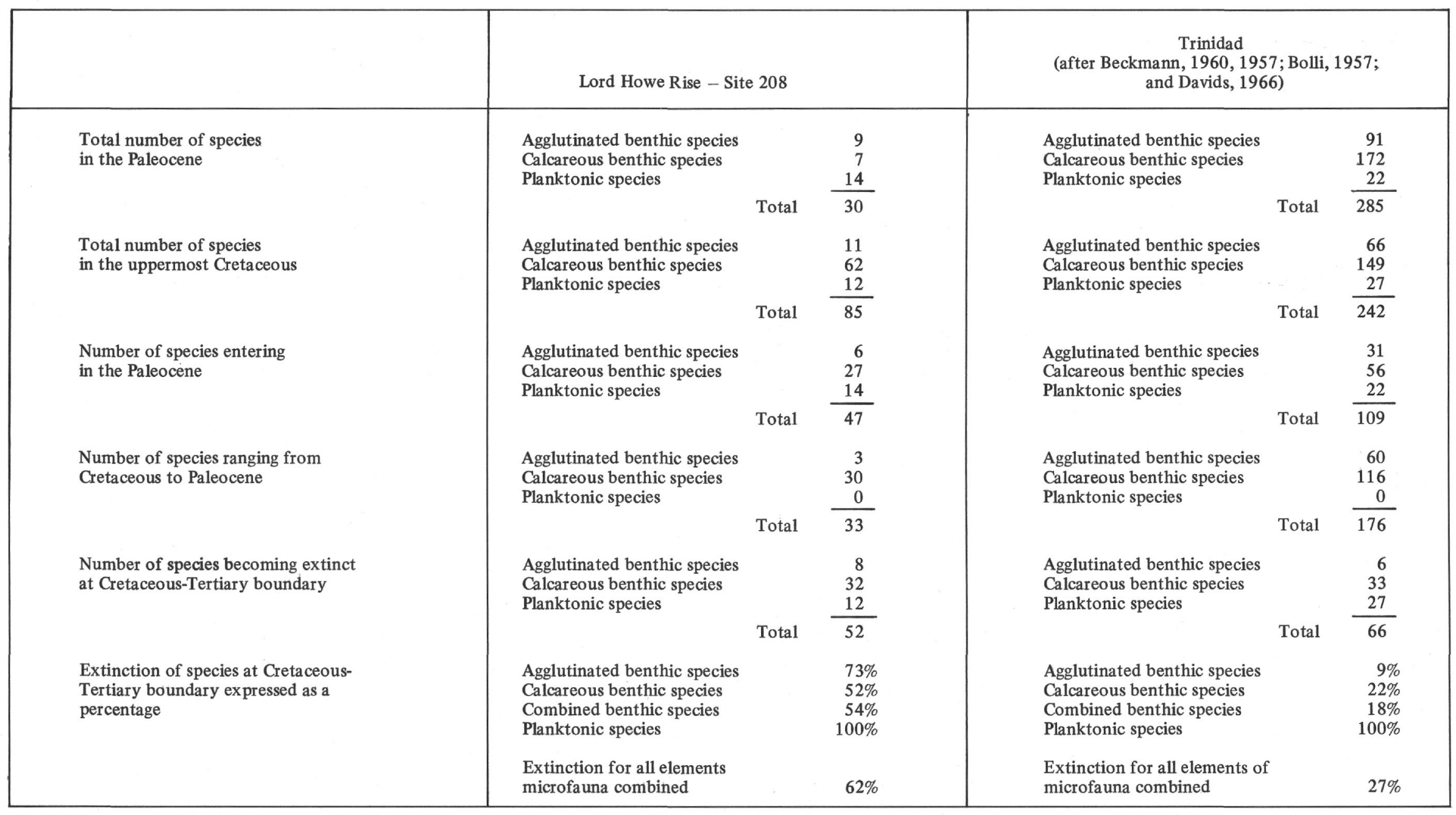

Figure 8. Table showing numbers of species of the various major groups restricted to the Maastrichtian or Paleocene, or present in both the Maastrichtian and Paleocene. Figures for Trinidad are also shown for comparison. 
Jenkins, D. G., 1971. New Zealand Cenozoic planktonic foraminifera. New Zealand Geol. Survey, Paleont. Bull. 42. $278 \mathrm{p}$.

Pessagno, E. A., 1967. Upper Cretaceous planktonic foraminifera from the western Gulf Coastal Plain. Palaeont. Am. v. 5, no. 37, 445 p.

Webb, P. N., 1966. New Zealand Late Cretaceous foraminifera and stratigraphy. Schotanus \& Jens N.V., Utrecht, 18 p.

1970. A preliminary statement on type material of New Zealand Upper Cretaceous, Paleocene and Eocene Foraminifera described by H. J. Finlay. New Zealand J. Geol. Geophys., v. 13, no. 3, p. 663.
1971. New Zealand Late Cretaceous (Haumurian) Foraminifera and stratigraphy: A summary. New Zealand J. Geol. Geophys., v. 14, no. 4, p. 795.

1972. A redescription of Frondicularia rakauroana (Finlay) from the Late Cretaceous (Maastrichtian) of New Zealand. Micropaleontology. v. 18 , no. 1, p. 94 .

1973. Preliminary comments on MaastrichtianPaleocene Foraminifera from Lord Howe Rise, Tasman Sea. Proceedings of Symposium on the Oceanography of the South Pacific (Wellington, February, 1972), UNESCO, p. 144. 



\section{PLATE 1}

All specimens from Site 208

Figure $1 \quad$ Heterohelix striata (Ehrenberg) 33-4(32-34 cm), X180.

Figure 2 Heterohelix striata (Ehrenberg) $33-4(32-34 \mathrm{~cm}), \times 140$.

Figure $3 \quad$ Heterohelix striata (Ehrenberg) $33-4(32-34 \mathrm{~cm}), \times 180$.

Figure $4 \quad$ Heterohelix glabrans (Cushman) $33-4(128-130 \mathrm{~cm}), \times 280$.

Figure 5 Pseudotextularia deformis (Kikoine) 33-2(114-116 cm), X200.

Figure 6 Pseudotextularia deformis (Kikoine) $33-2(30-32 \mathrm{~cm}), \times 187$.

Figure $7 \quad$ Pseudotextularia deformis (Kikoine) 33-2(112-114 cm), X187.

Figure $8 \quad$ Pseudotextularia deformis (Kikoine) 33-2(112-114 cm), X175.

Figure 9 Planoglobulina carseyae (Plummer) 33-2(30-32 cm), $\times 175$. 
PLATE 1
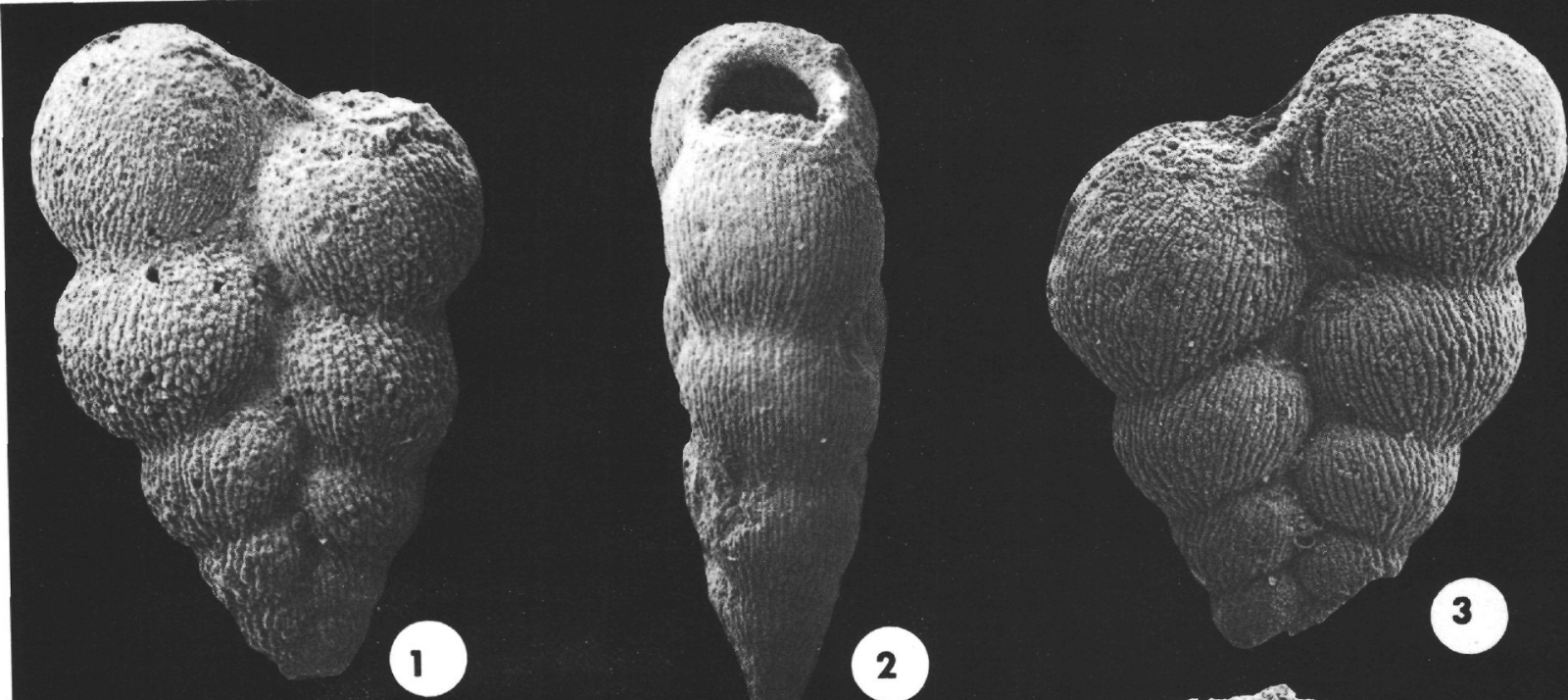

2
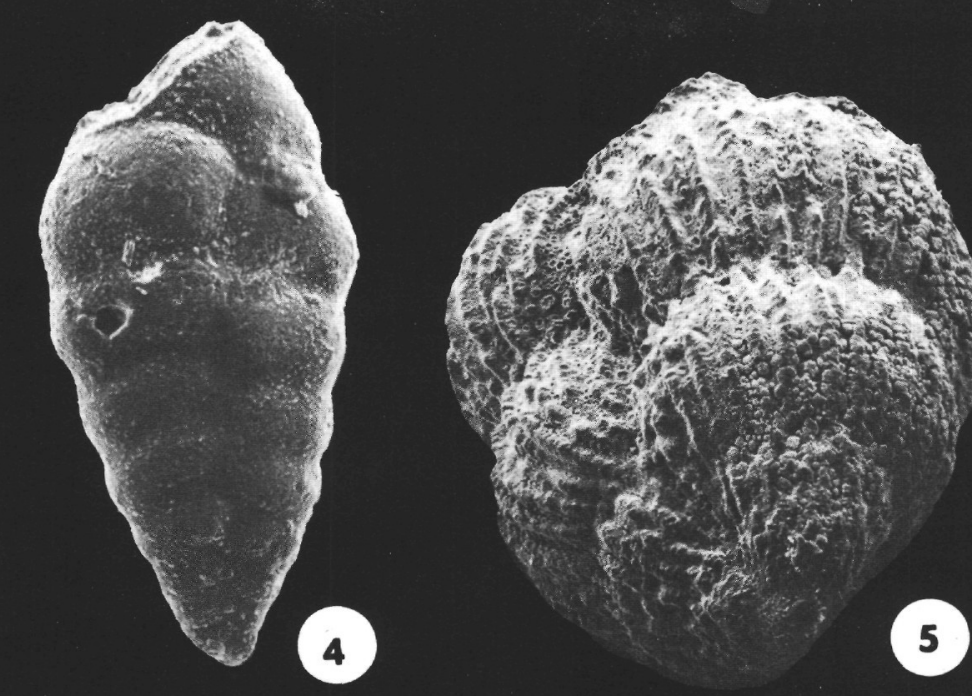

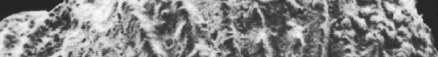

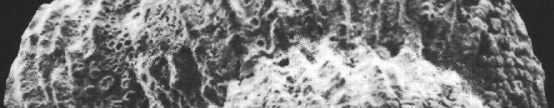

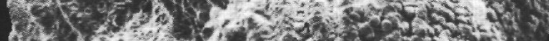

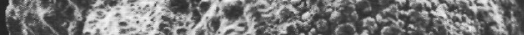

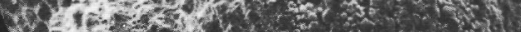
W.

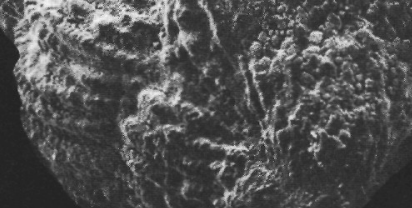

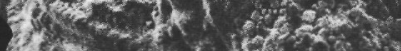

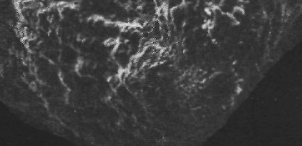

5
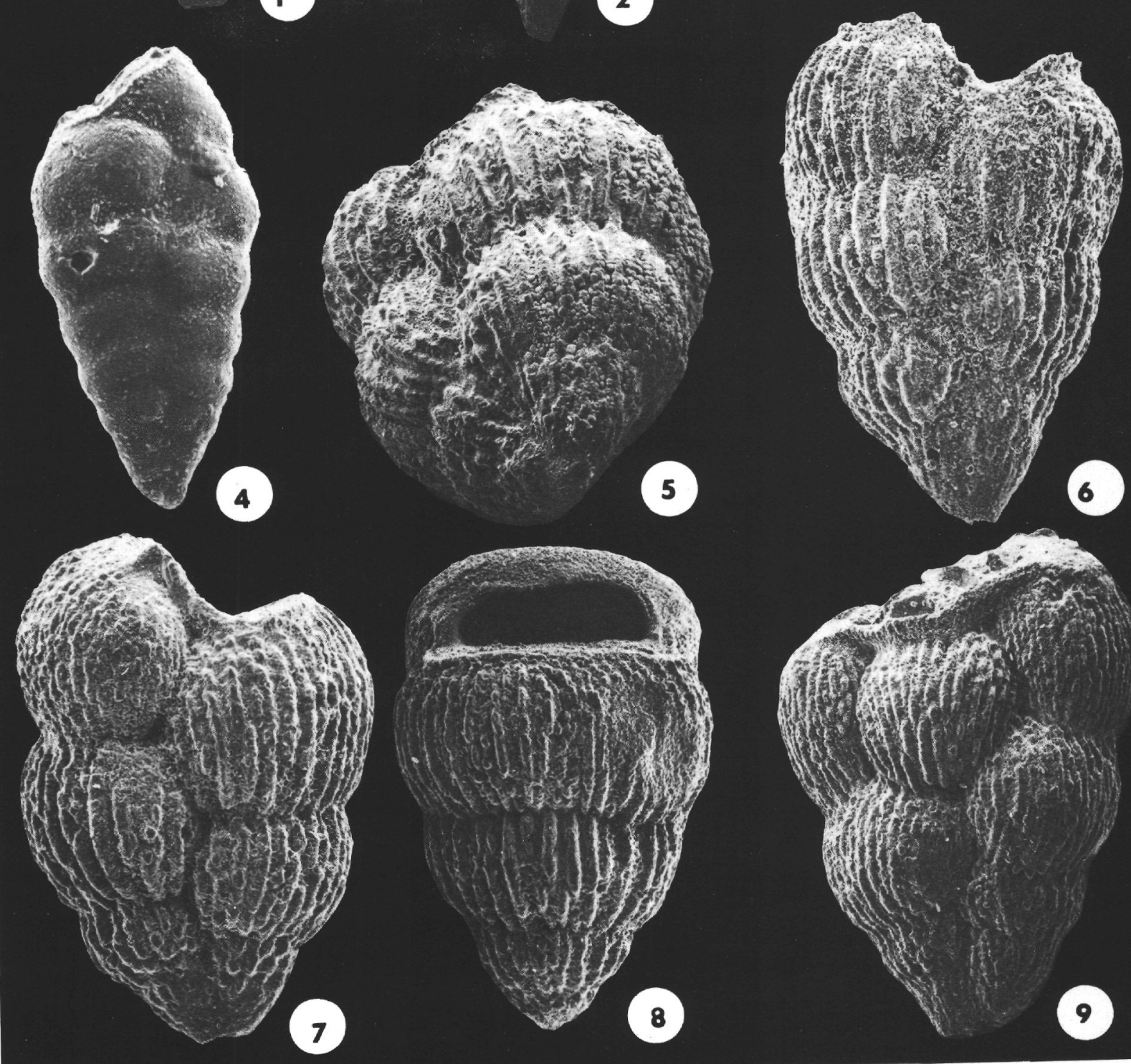


\section{PLATE 2}

All specimens from Site 208

Figure 1 Chiloguembelina wilcoxensis (Cushman and Ponton) 29-1 (45-47 cm), X280.

Figure 2 Chiloguembelina wilcoxensis (Cushman and Ponton) 29-1 (45-47 cm), X325.

Figure 3 Zeauvigerina teuria Finlay 30-1(112-114 cm), X375.

Figure 4 Zeauvigerina teuria Finlay $30-1(112-114 \mathrm{~cm}) \times 375$.

Figure $5 \quad$ Globigerinelloides volutus (White) $33-2(112-114 \mathrm{~cm}), \times 375$.

Figure $6 \quad$ Globigerinelloides volutus (White) 33-5 (20-22 cm), $\times 325$.

Figure $7 \quad$ Globigerinelloides volutus (White) $33-4(128-130 \mathrm{~cm}), \times 325$.

Figure 8 Globigerinelloides subcarinatus (Bronnimann) 33-5(94-96 cm), $\times 300$.

Figure 9 Globigerinelloides subcarinatus (Bronnimann) $33-4(128-130 \mathrm{~cm}), \times 260$. 
PLATE 2

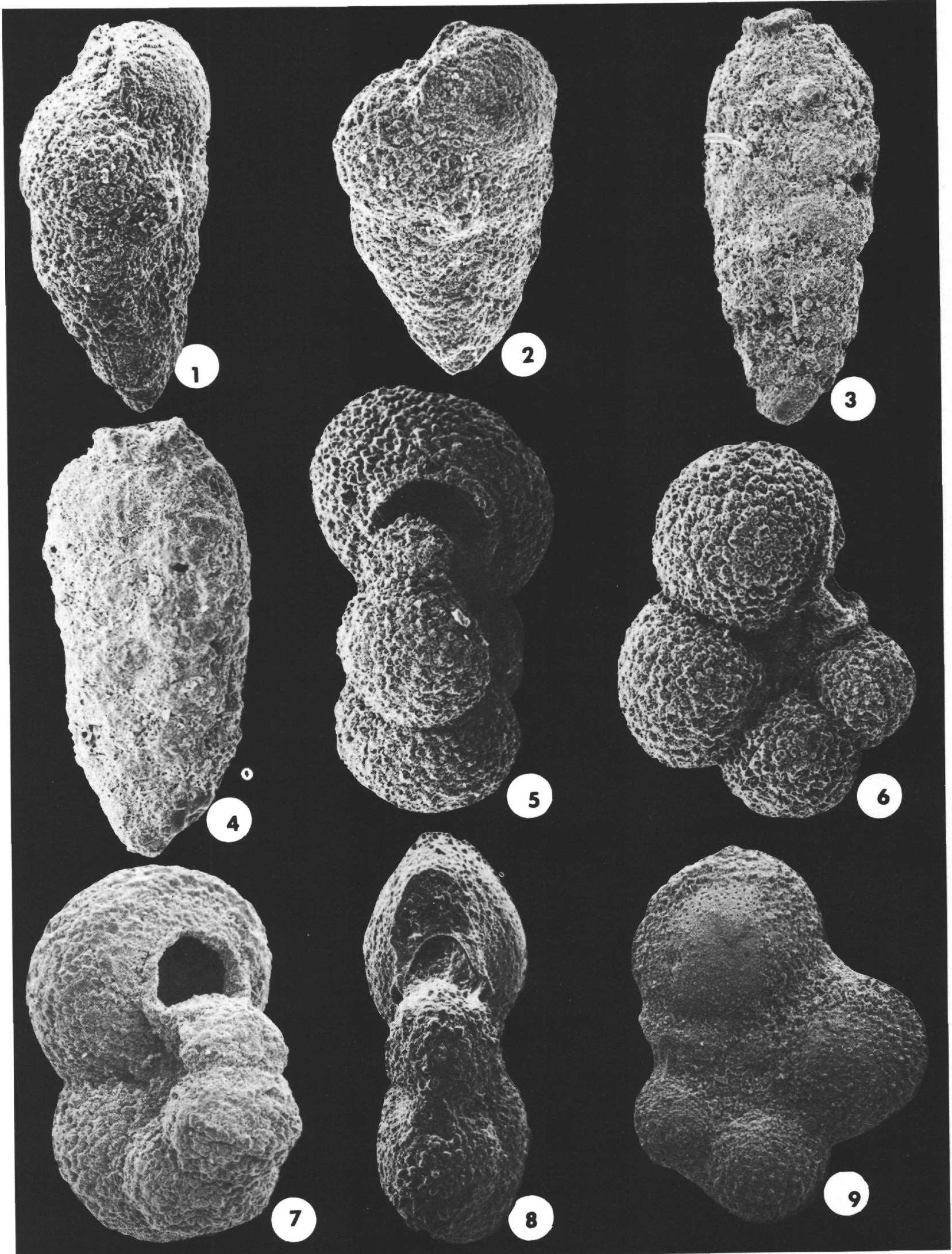


PLATE 3

All specimens from Site 208

Figure 1

Figure 2

Figure 3

Figure 4

Figure 5

Figure 6

Figure 7

Figure 8

Figure 9
Hedbergella monmouthensis (Olsson) 33-4(32-34 cm), X200.

Hedbergella monmouthensis (Olsson) 33-4(32-34 cm), X175.

Rugoglobigerina rugosa (Plummer) $33-5(20-22 \mathrm{~cm}), \times 220$.

Rugoglobigerina rugosa (Plummer) $33-5(20-22 \mathrm{~cm}), \times 220$.

Rugoglobigerina rugosa (Plummer) 33-4(32-34 cm), X220.

Rugoglobigerina rugosa (Plummer) $33-4(128-130 \mathrm{~cm}), \times 220$.

Rugoglobigerina rugosa (Plummer) 33-2(30-32 cm), $\times 220$.

Rugoglobigerina rugosa (Plummer) $33-5(20-22 \mathrm{~cm}), \times 200$.

Rugoglobigerina rotundata Bronnimann 33-5(20-22 cm), X150. 
PLATE 3

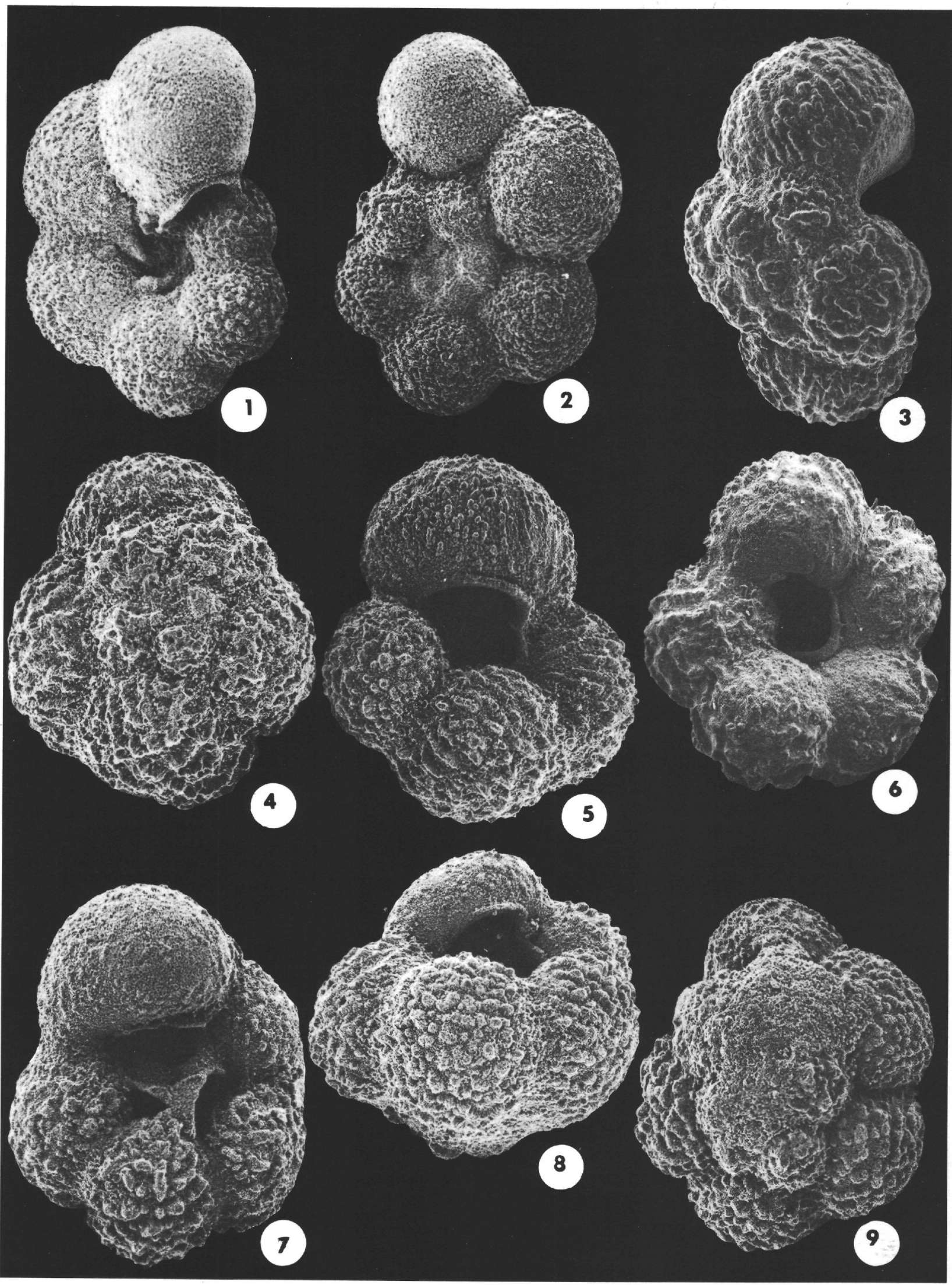




\section{PLATE 4}

All specimens from Site 208

Figure 1

Figure 2

Figure 3

Figure 4

Figure 5

Figure 6

Figure 7

Figure 8

Figure 9
Globotruncana (Rugotruncana) circumnodifer (Finlay) 33-5 $(94-96 \mathrm{~cm}), \times 145$.

Globotruncana (Rugotruncana) circumnodifer (Finlay) 34-2(127-129 cm), X145.

Globotruncana (Rugotruncana) circumnodifer (Finlay) 33-5(94-96 cm), X145.

Globotruncana (Rugotruncana) circumnodifer (Finlay) $34-2(127-129 \mathrm{~cm}), \times 145$.

Globotruncana (Abathomphalus) mayaroensis Bolli $33-3(26-28 \mathrm{~cm}), \times 185$.

Globotruncana (Abathomphalus) mayaroensis Bolli $33-3(26-28 \mathrm{~cm}), \times 185$.

Globotruncana (Abathomphalus) mayaroensis Bolli 33-2(112-114 cm), X185.

Globotruncana (Abathomphalus) mayaroensis Bolli 33-2(112-114 cm), X130.

Globotruncana (Abathomphalus) mayaroensis Bolli 33-2(112-114 cm), X120. 
PLATE 4

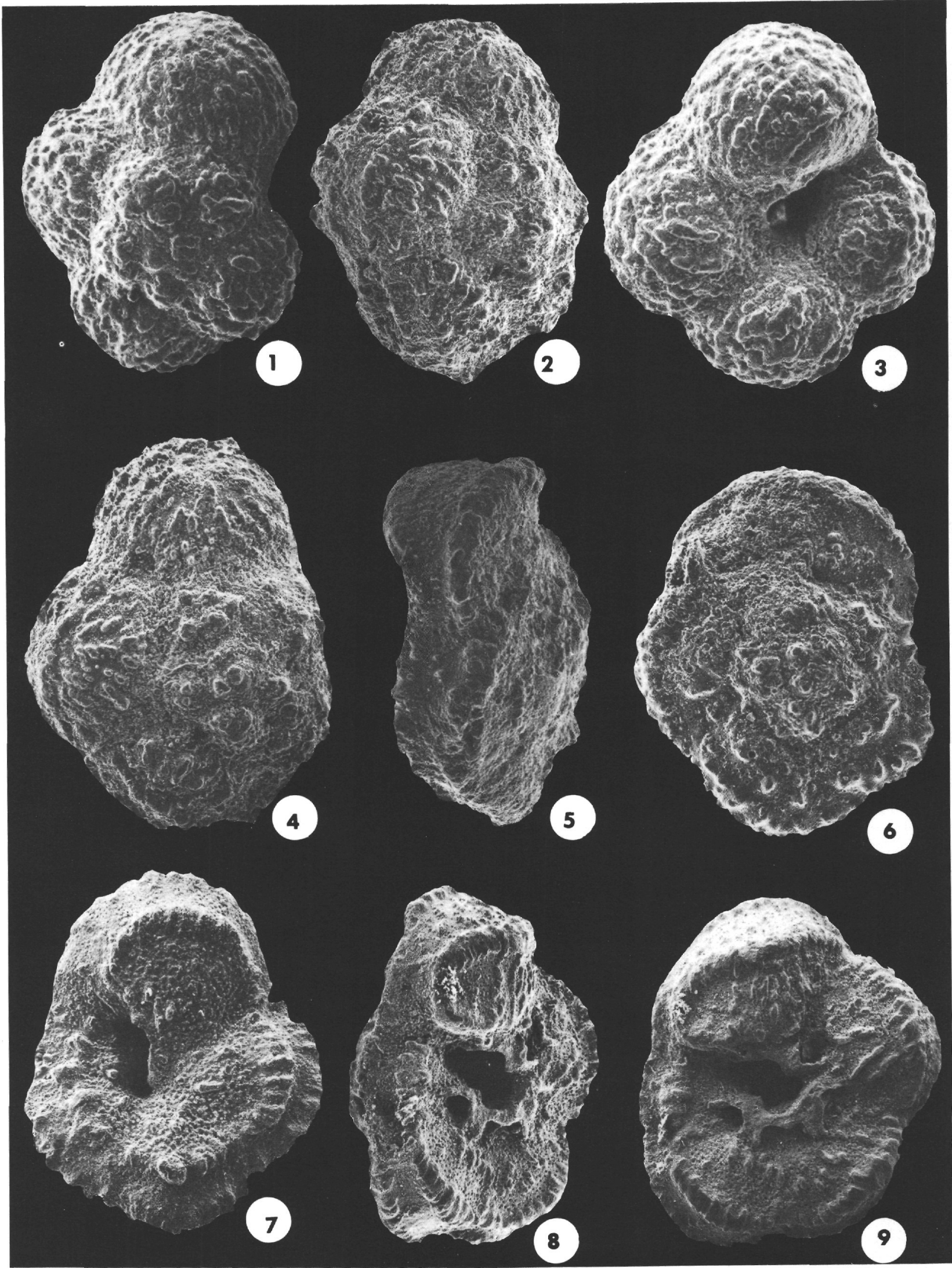




\section{PLATE 5}

All specimens from Site 208

Figure 1

Figure 2

Figure 3

Figure 4

Figure 5

Figure 6

Figure 7

Figure 8

Figure 9
Globorotalia pseudobulloides (Plummer) $30-5(112-114 \mathrm{~cm}), \times 220$.

Globorotalia pseudobulloides (Plummer) $30-5(112-114 \mathrm{~cm}), \times 220$.

Globorotalia pseudobulloides (Plummer) 30-5(112-114 cm), X200.

Globigerina triloculinoides Plummer 29-3(118-120 cm), X260.

Globigerina triloculinoides Plummer 29-3(118-120 cm), X240.

Globorotalia ehrenbergi Bolli 29-3(118-120 cm), X220.

Globorotalia pseudomenardii Bolli 29-1(45-47 cm), X280.

Globorotalia pseudomenardii Bolli 29-1(45-47 cm), X185.

Globorotalia pseudomenardii Bolli 29-1(45-47 cm), X260. 
PLATE 5
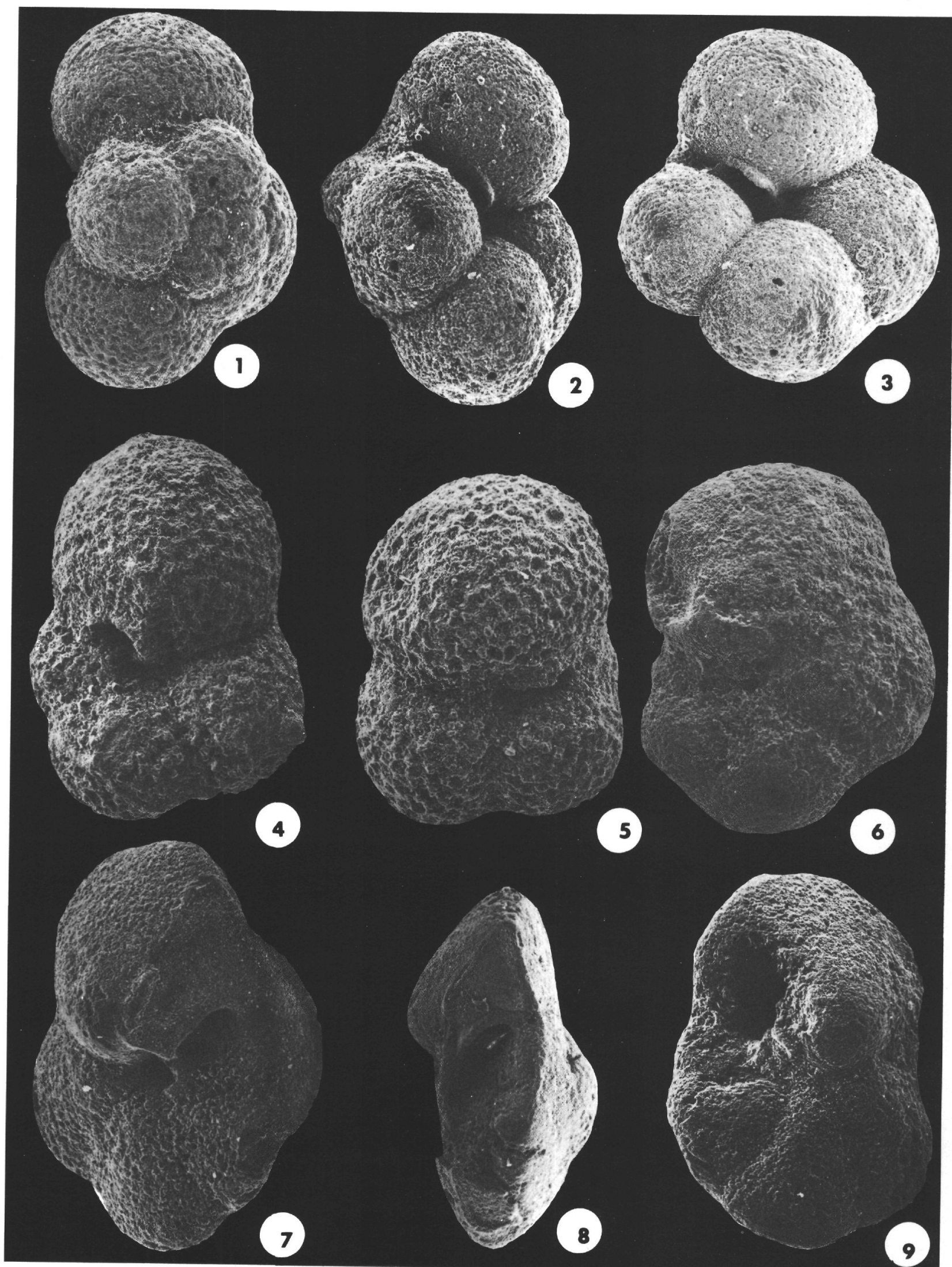
PLATE 6

All specimens from Site 208

Figure $1 \quad$ Globorotalia uncinata Bolli 29-4(31-33 cm), X220.

Figure 2 Globorotalia uncinata Bolli 29-4(31-33 cm), $\times 220$.

Figure $3 \quad$ Globorotalia uncinata Bolli 29-5(108-110 cm), $\times 220$.

Figure 4 Globorotalia uncinata Bolli-angulata (White) $39-6(53-55 \mathrm{~cm}), \times 220$.

Figure $5 \quad$ Globorotalia mckannai (White) 29-2(118-120 cm), X220.

Figure 6 Globorotalia mckannai (White) 29-2(118-120 cm), X220.

Figure $7 \quad$ Globorotalia angulata (White) 29-6(53-55 cm), X220.

Figure $8 \quad$ Globorotalia mckannai (White) 29-2(118-120 cm), X220.

Figure 9 Globorotalia acarinata (Subbotina) 29-1(45-47 cm), X220. 
PLATE 6

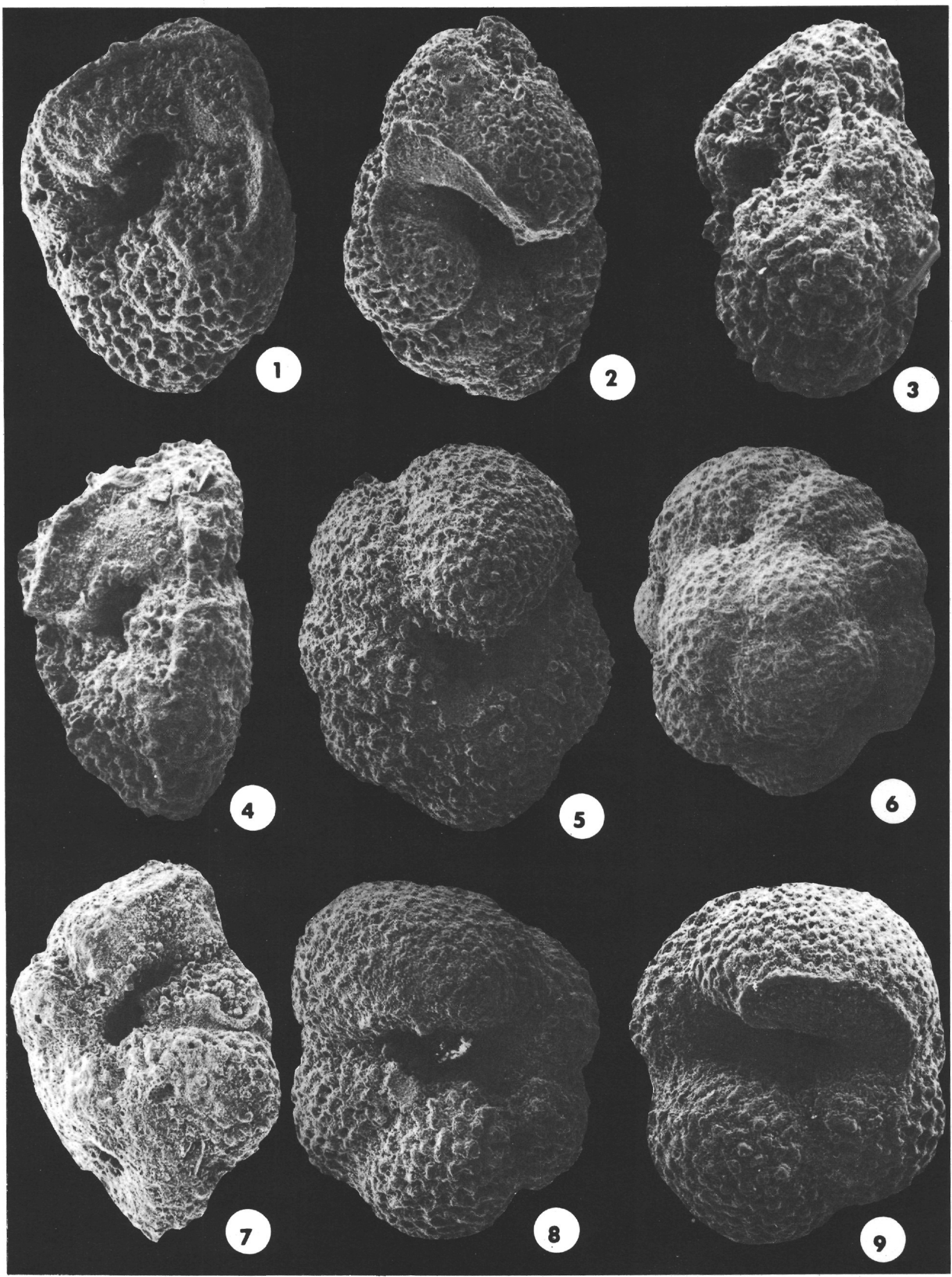

